\title{
A portable, low-cost relaxed eddy accumulation (REA) system for quantifying ecosystem-level fluxes of volatile organics
}

\author{
Chinmoy Sarkar ${ }^{\mathrm{a}, *}$, Andrew Turnipseed ${ }^{\mathrm{b}}$, Stephen Shertz ${ }^{\mathrm{c}}$, Thomas Karl ${ }^{\mathrm{d}}$, Mark Potosnak ${ }^{\mathrm{e}}$, \\ Jianhui Bai ${ }^{\mathrm{f}}$, Dominique Serça ${ }^{\mathrm{g}}$, Damien Bonal ${ }^{\mathrm{h}}$, Benoit Burban ${ }^{\mathrm{i}}$, Paula R.C. Lopes ${ }^{\mathrm{j}}$, \\ Oscar Vega $^{k}$, Alex B. Guenther ${ }^{a}$
}

a Department of Earth System Science, University of California, Irvine, 92697, CA, USA

b $2 B$ Technologies Inc., 2100 Central Ave \# 105, Boulder, CO, 80301, USA

${ }^{\mathrm{c}}$ National Center for Atmospheric Research, PO Box 3000, Boulder, CO, 80307-3000, USA

${ }^{\mathrm{d}}$ Institute for Atmospheric and Cryospheric Sciences, University of Innsbruck, Innsbruck, Austria

${ }^{\mathrm{e}}$ Department of Environmental Science and Studies, DePaul University, $1110 \mathrm{~W}$ Belden Ave, Chicago, IL, 60614, USA

${ }^{\mathrm{f}}$ LAGEO, Institute of Atmospheric Physics, Chinese Academy of Sciences, Beijing, 100029, China

${ }^{g}$ Laboratoire d'Aérologie, Université de Toulouse, CNRS, UPS, France

${ }^{\mathrm{h}}$ Université de Lorraine, AgroParisTech, INRAE, UMR Silva, 54000, Nancy, France

${ }^{\text {i }}$ UMR EcoFoG, INRAE, CNRS, Cirad, Université des Antilles, Université de Guyane, 97310, Kourou, French Guiana

${ }^{\mathrm{j}}$ Instituto de Pesquisas Energéticas e Nucleares (IPEN/CNEN/USP-SP), Sao Paulo, Brazil

${ }^{\mathrm{k}}$ Centro de Química e Meio Ambiente, Instituto de Pesquisas Energéticas e Nucleares, São Paulo, 05508-000, Brazil

Quantification of biogenic volatile organic compound (BVOC) fluxes into the atmosphere is crucial to understand their role in atmospheric oxidation and biogeochemical cycles. BVOC flux measurements were carried out in nine forest ecosystems using a relaxed eddy accumulation (REA) based sampling system, which is easily transportable, simple to operate and designed to be low-cost and therefore can easily be deployed at multiple remote locations. The REA measurements were carried out during daytime between 06:00 and 18:30 (Local Time) with a flux averaging period of 30 min. A detailed description of the REA sampling setup, operational procedure and validation by comparison with full eddy covariance (EC) BVOC flux measurements is provided. BVOC flux measurements from established long-term carbon and water flux tower sites in nine forest ecosystems are compared including Manitou Forest Observatory in Colorado, USA (pine woodland forest), Niwot Ridge Amer-iFlux site in Colorado, USA (subalpine forest), Deer Canyon Preserve in New Mexico, USA (pinyonjuniper for-est), Lei bamboo forest site near Taihuyuan, China, Qianyanzhou ChinaFLUX site in China (pine forest), Baskett Wildfire Refuge MOFlux site in Missouri, USA (deciduous oak forest), University of Michigan Biological Station PROPHET site in Michigan, USA (mixed deciduous forest), Changbai Mountain Forest Research Station in China (mixed deciduous forest) and the Guyaflux site (GF-Guy) in French Guiana (tropical rainforest). BVOC flux measurements using our REA setup confirm dominance of 2,3,2- methylbutenol (2,3,2-MBO) at the Manitou Forest Observatory and Niwot Ridge sites in Colorado. Monoterpene fluxes measured by REA showed good agreement (within $\pm 10 \%$ ) with monoterpene fluxes measured by PTR-MS at the Manitou Forest Observatory. The MOFlux site in Missouri was dominated by isoprene emissions (average flux of $\sim 9.5 \mathrm{mg} \mathrm{m}^{-2} \mathrm{~h}^{-1}$ ) whereas the Deer Canyon site was dominated by $\alpha$-pinene emissions (average flux $\sim 0.73 \mathrm{mg} \mathrm{m}^{-2} \mathrm{~h}^{-1}$ ). Mixed deciduous forest sites at the PROPHET Station in Michigan and Changbai Mountain Forest Research Station in China pri-marily emitted isoprene along with some $\alpha$-pinene, $\beta$-pinene and d-Limonene. Isoprene and $\alpha$-pinene were the dominant BVOCs emitted from the subtropical Lei bamboo plantation at the Taihuyuan site in China while the pine forest site at Qianyanzhou in China were dominated by $\alpha$-pinene emissions along with significant isoprene. BVOC measurements across different seasons (during 2009-2011) at a tropical forest site in French Guiana

\footnotetext{
* Corresponding author.

E-mail address: chinmoysarkar8@gmail.com (C. Sarkar).
} 
(Guyaflux site) revealed the dominance of isoprene emissions during all seasons. Irrespective of the type of the forest ecosystem, $\alpha$-pinene was among the dominant monoterpenes emitted from all nine forests.

\section{Introduction}

Volatile organic compounds (VOCs) play a critical role in atmospheric chemistry through their participation in photochemical oxidation and the formation of organic aerosols (Hoffmann et al., 1997; Hallquist et al., 2009). On a global scale, the major source of these VOCs is biogenic processes (Guenther et al., 2006). Therefore, to understand atmospheric chemistry pertaining to oxidants and aerosol formation, a thorough accounting of biogenic VOCs (BVOCs) is required. However, the large variety of vegetation and ecosystems as well as temporal land use changes (disturbances, etc.), make this an exceedingly difficult task.

Current BVOC emission models (Guenther et al., 1995, 2012) typically group vegetation types into either broad plant functional types (PFTs) or specific vegetation types, which are then assigned an emission capacity for each BVOC category. Temporal variations are then based on emission algorithms driven by observed meteorological variables (primarily radiation and temperature). Although it is desirable to be able to experimentally measure emission capacities of individual plants to build these emission models, the large diversity in vegetation coupled with the added variability of the environmental parameters (i.e., radiation, soil moisture) within natural canopies makes this task a near impossibility. This gets further complicated by the temporal variations in these natural systems (phenology changes, water stress) which are currently poorly represented by global BVOC models. Micrometeorological flux techniques provide a method to observationally determine BVOC emissions over canopy to landscape scales of hectares to a few square kilometers which can be used to parameterize models based on ecosystem type. This is especially important in extremely diverse ecosystems such as tropical forests which can contain hundreds of tree species within a relatively small area (few hectares).

Eddy covariance (EC) is the most direct and robust micrometeorological flux measurement method which involves correlating concentration fluctuations with changes in vertical wind velocity (Baldocchi et al., 1988; Lenschow, 1995). EC requires simultaneous fast measurements $(<1 \mathrm{~s})$ of 3-dimensional wind velocities and the concentration of the species of interest several meters above a suitable vegetation canopy. These measurements must be made over all the relative time scales of turbulent transport within the atmospheric surface layer. Therefore, the EC method requires fast measurements $(<1 \mathrm{~s})$ that can then be averaged for longer time scales $(0.5-1 \mathrm{~h})$. This requirement contrasts with traditional analytical methods that have been used for determining atmospheric BVOC concentrations that require longer sampling times. Recent advances in the application of the chemical ionization mass spectrometry technique have made such fast BVOC determinations possible (Karl et al., 2004; Kaser et al., 2013a; Sarkar et al., 2020). However, this instrumentation is relatively expensive and requires considerable expertise to operate in the field. In addition, these mass spectrometers require substantial power which is often not available at flux tower field sites and are difficult to maintain in working order over a longer time period (e.g. seasonal studies). Furthermore, CIMS techniques can only identify VOCs based on molecular formula and cannot distinguish different isomers which can have different atmospheric oxidation rates. For example, CIMS techniques can measure the sum of monoterpenes, but cannot speciate which monoterpenes are present without some preliminary separation technique.

Therefore, there is a need for alternative flux techniques like Relaxed Eddy Accumulation (REA) which are relatively inexpensive, require minimal power and can be interfaced with slower analytical methods (Rinne et al., 2016). The REA method segregates air samples based on rapid $(10 \mathrm{~Hz})$ wind fluctuations to different storage reservoirs that can be analyzed later by slow methods. Since it was initially proposed by
Businger and Oncley (1990), the REA technique has been adapted to measure ecosystem scale fluxes of trace species ranging from $\mathrm{CO}_{2}$ (Oncley et al., 1993; Pattey et al., 1993), to aerosols (Schery et al., 1998; Gaman et al., 2004), to BVOCs (Bowling et al., 1998; Graus et al., 2006; Ciccioli et al., 2003; Gallagher et al., 2000; Greenberg et al., 2003; Zhu et al., 1999; Olofsson et al., 2003). The complexity of these previous REA measurements have ranged from simple (Bowling et al., 1998) to rather complex (Nie et al., 1995; Baum and Ham, 2009; Arnts et al., 2013). As our goal is to provide measurements at a wide range of locations, we describe in this manuscript a REA-based sampling system that is easily transportable, simple to operate and designed to be relatively low-cost. This allows these systems to be deployed across a wide range of sites with the goal of obtaining BVOC flux measurements across existing flux tower networks to determine the magnitude of compounds being emitted and to estimate their emission capacities over a variety of ecosystems. We describe here the deployment of the REA system at nine forested sites and compare the observed fluxes, including measurements at three sites that have previously been reported and observations from an additional six sites that have not previously been published.

\section{Methodology}

\subsection{Relaxed eddy accumulation (REA) technique}

The technique of relaxed eddy accumulation (REA) segregates air into different storage containers based on the direction of the instantaneous ( $>4 \mathrm{~Hz}$ sampling rate) vertical wind velocities. In effect, this replaces the need for fast concentration measurement (for the EC technique) with fast valving and flow control (Lenschow, 1995). With REA, air samples are accumulated over a specific period of time (flux averaging period - typically 15-60 mins) in two storage reservoirs - one for upward moving air and one for downward moving air. At the end of this time period, the two reservoirs are analyzed and the area-averaged flux, which is proportional to the concentration difference between the "up" and "down" reservoirs, is calculated as described by Businger and Oncley (1990):

$F_{i}=\sigma_{w} b\left(C_{u p}-C_{d o w n}\right)$

In this equation, $\sigma_{w}$ is the standard deviation of the vertical wind velocity, $b$ is an empirical scaling coefficient (described below) and $C_{\text {up }}$ and $C_{\text {down }}$ are the concentrations (densities) of the species of interest in the up and down reservoirs, respectively. The $b$-coefficient can be determined from the heat flux (the covariance of $w$ and $T$ or $w^{\prime} T^{\prime}$ ) by conditionally sampling the sonic-derived temperature to obtain average temperatures in the updrafts and downdrafts, $T_{\text {up }}$ and $T_{\text {down. }}$. Rearranging equation (1) will then provide:

$b=\frac{w^{\prime} T^{\prime}}{\sigma_{w}\left(T_{u p}-T_{\text {down }}\right)}$

Substitution of equation (2) into (1) yields:

$F_{i}=\frac{w^{\prime} T}{\left(T_{u p}-T_{\text {down }}\right)}\left(C_{u p}-C_{\text {down }}\right)$

This expression is similar to that of the modified Bowen ratio technique for measuring fluxes from gradient concentrations (Hicks and Wesely, 1978) and assumes that heat and the compound of interest are both transported in a similar fashion (scalar similarity). We include a third reservoir, denoted here as a "neutral". Air is sampled onto the neutral cartridge when the absolute vertical wind velocity is less than the chosen threshold. The use of a threshold (or sampling dead band) 
enhances the concentration difference between the up and down reservoirs (Businger and Oncley, 1990; Bowling et al., 1998).

The system described here is designed to sample air directly onto adsorbent cartridges for sampling volatile organic compounds (VOCs). It consists of a datalogger (CR1000, Campbell Scientific Inc., Logan, UT)), a 3-D sonic anemometer (RM Young, Model $81000 \mathrm{~V}$ ) and a sampling segregator where air is sampled onto the adsorbent cartridges. The datalogger receives the wind velocity data from the anemometer at a sampling rate of $10 \mathrm{~Hz}$ and then controls the valves within the sampling segregator, selecting the proper cartridge based on the direction of the instantaneous vertical wind velocity at the time of the sample capture. Fig. 1 shows the detailed schematic of our REA system.

The segregator consists of 8 inlets which are isolated from a manifold with fast solenoid valves ( $<10 \mathrm{~ms}$; Numatics, S-series miniature valves). Six of these inlets are designated as up/down pairs, while the inlets 7 and 8 are assigned to a neutral sample and a bypass with no adsorbent cartridge attached (Fig. 1). A mass flow controller (MFC, MKS Instruments, M100B) and finally a small diaphragm pump (KNF Nueberger, UNMP015M) is attached to the downstream side of the manifold. The analog signal from the mass flow controller is measured and logged by the main datalogger. The pump, MFC and the solenoid valves are the major contributors to the total system power consumption which was measured to be $<20$ Watts. Therefore, it is conducive for operation using batteries/solar panels at remote locations.

Adsorbent cartridges are connected to each segregator inlet via $1 / 4 "$ Swagelok with a Teflon ferrule. On the upstream side of the cartridge, a filter is attached for the removal of ozone which can react with the preconcentrated VOCs on the cartridges. These filters consisted of 25 $\mathrm{mm}$ glass fiber filters (Pall Scientific, Acrodisc filters) impregnated with either potassium iodide (Greenberg et al., 1994) or sodium thiosulfate (Helmig, 1997) which have both been shown to be effective at removing ozone without significant loss of most VOC analytes (Helmig, 1997; Arnts et al., 2013).

A typical startup operation involved opening the bypass valve (with no adsorbent cartridge) while the datalogger collected wind data to initialize the conditional sampling (described below) as well as allowing adequate warm-up time for the pump and MFC. Sampling was initiated by changing a logical variable on the datalogger keypad. Once engaged, the system would begin conditional sampling for the next 30 mins using the first pair of cartridges. The REA would then proceed through each of the 3 pairs of cartridges, resulting in three consecutive flux measurements. The typical flux averaging period was set to $30 \mathrm{mins}$, thus cartridges would have to be exchanged every 90 mins. All three flux periods shared a common neutral cartridge. This neutral cartridge has a drawback of possible breakthrough of lighter hydrocarbons due to the large sample volume from all three samples. This limits the use of this cartridge for quantitative concentration assessment. However, the large sample volumes have the advantage of providing good signal to noise ratio for identifying peaks in the chromatograms.

The datalogger conditionally samples the sonic-derived temperature and computes $T_{u p}, T_{d o w n}$ as well as the covariance of $w$ and $T\left(w^{\prime} T^{\prime}\right)$ and $\sigma_{w}$. Along with the accumulated volumes in the up and down reservoirs (from integration of the MFC signal), it saves all the necessary values to compute the flux according to equation (1). The mass accumulated in the up/down reservoirs (cartridges) are then determined by gas chromatography (GC) coupled with both flame ionization (FID) and mass spectrometric detectors (MS). The concentrations are then determined using the amount of volume that was passed through each respective reservoir.

At the beginning of each flux averaging period, to be able to segregate the sample flow, REA requires an estimation of the mean vertical wind velocity $(\bar{w})$ and $\sigma_{w} . \bar{w}$ is required to determine the direction of the instantaneous vertical wind velocity $\left(w^{\prime}=w(t)-\bar{w}\right)$ and $\sigma_{w}$ is needed to calculate the sampling threshold. The threshold is a range of small $w^{\prime}$ values, centered around $\bar{w}$, over which the sample air is collected through the "neutral" line. The concentration of the neutral sample is not necessary for the flux calculation. We have adapted the recommendations of Businger and Oncley (1990) and used a threshold of \pm 0.6 $\sigma_{w}$. Since only larger eddies (with larger concentration fluctuations) are sampled into the up/down reservoirs, the use of this "deadband" effectively increases the differences in the measured concentrations $\left(C_{u p}-\right.$ $C_{\text {down }}$ ), easing restrictions on the analytical technique used. Note that the $b$-coefficient must also be computed (from Eqn. (2)) using the same deadband as it will affect the value of this scaling coefficient.

Estimation of both $\bar{w}$ and $\sigma_{w}$ are required at the beginning of a flux averaging period. However, knowledge of the final values ahead of time is not possible, leading to a constraint to the REA technique. For long term deployments, $\bar{w}$ was obtained from rotation of the 3-D wind velocities to long-term wind coordinates (Wilczak et al., 2001). However, most of the deployments described here were relatively short or required either moving or powering off the system between measurements. Therefore, upon initial startup of the REA, wind statistics were measured

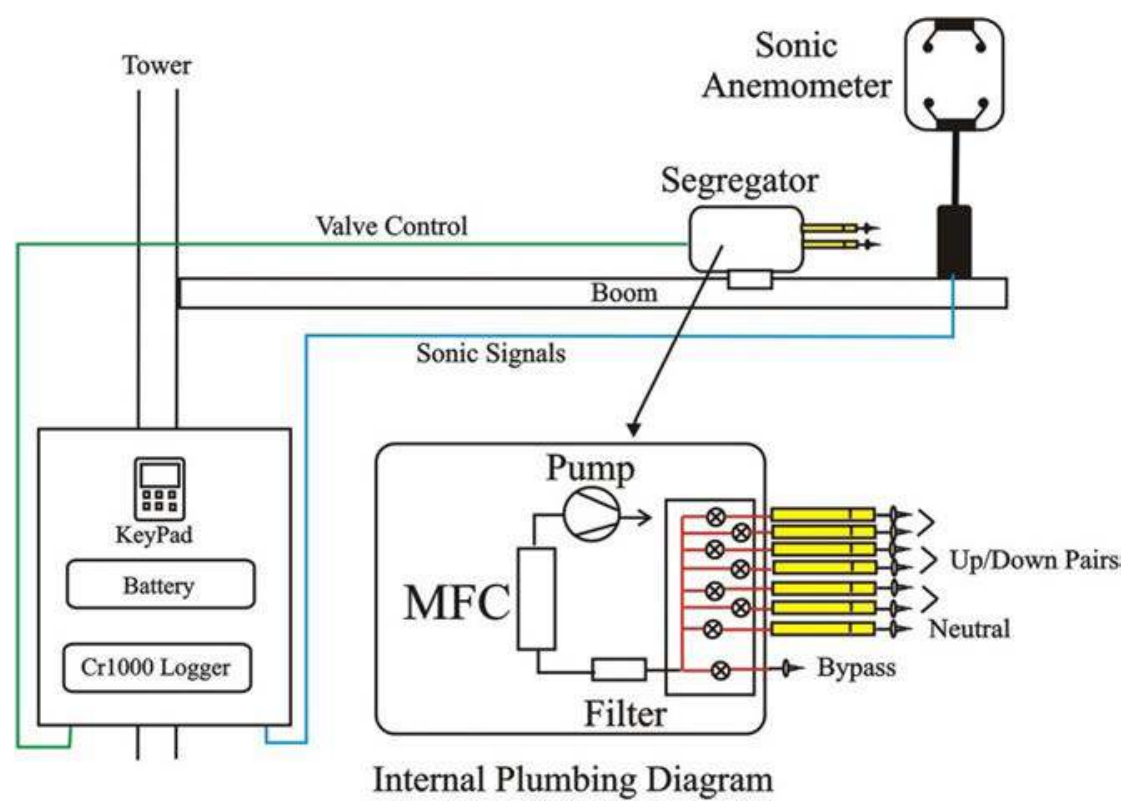

Fig. 1. Schematic of the REA setup. 
for at least 15 mins before collecting air samples to obtain initial estimates of $\bar{w}$ and $\sigma_{w}$. Thereafter, initial estimates of $\bar{w}$ and $\sigma_{w}$ for a given flux period were obtained from the previous 30 mins flux averaging period. We have found this to be effective when using the similar Disjunct Eddy Accumulation (DEA) technique (Turnipseed et al., 2009) to correct for small biases in $\bar{w}$.

\subsection{VOC collection and analysis}

Two-stage adsorbent cartridges (Markes International Ltd., USA or packed in-house) were used to collect VOC samples using the REA technique. The first stage was filled with $150 \mathrm{mg}$ Tenax-TA or Tenax-GR which has been shown to be satisfactory for the collection of many heavier biogenic species including monoterpenes and sesquiterpenes (Helmig and Vierling, 1995; Arnts, 2010). The second stage was $150 \mathrm{mg}$ Carbograph5 which is a stronger adsorbent used to trap lighter hydrocarbon species such as isoprene (Dettmer et al., 2000). Laboratory tests showed no breakthrough of isoprene or major terpenes ( $\alpha$-pinene, camphene) with the sample volumes collected for flux calculations (i.e., the up and down reservoirs) with REA.

VOCs were analyzed by thermal desorption (TD) followed by gas chromatographic (GC, Agilent 7890A) separation and detection by both flame ionization (FID) and mass selective (MSD, Agilent 5975C) detectors. Thermal desorption was accomplished via a 2-stage process, where the adsorbent cartridge was initially desorbed at $275^{\circ} \mathrm{C}$ while purging with a flow of UHP Helium using a commercial TD-autosampler (Markes International Ltd., Series 2 Ultra). The sample was then transferred via a heated line to a focusing trap that was packed with Tenax-TA and cooled to $0^{\circ} \mathrm{C}$ via a Peltier cooler (Markes International Ltd., Unity 1). Once the entire sample was transferred to this intermediate trap, it is rapidly heated to $300^{\circ} \mathrm{C}$ and injected onto the GC. The GC is cryofocused at $-30^{\circ} \mathrm{C}$ and then the temperature programmed up to $275^{\circ} \mathrm{C}$. Separation takes place on a capillary GC column (Restek Rxi-5Sil MS, $0.25 \mathrm{~mm}$ i.d., $250 \mu \mathrm{m}$ film, $30 \mathrm{~m}$ ) before the sample is split between the two detectors (FID and MSD).

The system was calibrated daily by filling adsorbent cartridges with a secondary standard consisting of isoprene and camphene. This isoprene/ camphene standard was calibrated relative to a NIST-certified butane/ benzene gas standard as well as a NIST-certified neohexane gas standard. When possible, the FID was used to quantitate analytes. Since the detector response is based on the number of carbon atoms within a molecule, it allows quantification of a wide range of carbon-containing compounds from the use of a single standard compound.

However, at the low sample masses often encountered in the ambient REA samples, quantitation with the FID becomes problematic due to interfering and overlapping peaks. Therefore, it was often necessary to use selective ion monitoring (SIMs) with the MSD to obtain quantitative information. For most of the BVOCs, this was accomplished by loading cartridges with samples from uncalibrated gas standards created from the pure liquids in the lab or by just using a syringe to sample headspace from the pure liquids. Analysis of these samples relative to the isoprene/ camphene standard allowed us to compute response factors relative to either the mass 68 ion of isoprene or the mass 93 ion of camphene.

\subsection{Measurement sites and experimental setup}

To demonstrate the utility of this REA sampling system for field deployment and taking samples at multiple locations, nine sites were used for testing and the measurements have subsequently been analyzed and described. Table 1 provides a brief description of the sites from which data are presented, including type of vegetation, LAI, etc. The REA was installed $\sim 6-10 \mathrm{~m}$ above the canopy at all sites. Typically, the sonic anemometer was installed on $\mathrm{a} \sim 1 \mathrm{~m}$ boom facing into the prevailing winds. The segregator was mounted on the same boom (in some deployments, a second parallel boom was used) with the inlets facing towards the base of the anemometer. The boom was constructed of aluminum strut (L30, Bosch-Rexroth) and a Teflon slide was attached to the outside of the segregator box such that the segregator could slide along the boom. Therefore, the segregator could be pulled close to the tower to facilitate removing/attaching cartridges and then slid into close proximity to the anemometer for sampling without affecting the sonic anemometer orientation. The cartridge inlets were typically separated by $\sim 35-50 \mathrm{~cm}$ from the anemometer measurement path. Although it is desirable to minimize this separation, the size of the segregator $(26 \mathrm{~cm}$ length, $16 \mathrm{~cm}$ width, $10 \mathrm{~cm}$ height)) could negatively impact wind flows around the anemometer head if placed in close proximity. For tall canopies, such as the ones studied here, corrections for sensor separation are generally rather small ( $<8 \%$ reduction in flux, Moore, 1986) and were neglected.

The REA was compared to eddy covariance (EC) measurements in three different experiments. Two of these were conducted at the Manitou Forest Observatory (2009 and 2011) and the third at the

Table 1

Description of the REA measurement sites.

\begin{tabular}{|c|c|c|c|c|c|}
\hline Measurement Site & $\begin{array}{l}\text { Latitude/ } \\
\text { Longitude }\end{array}$ & Ecosystem & Dominant Species & $\mathrm{LAI}^{\mathrm{a}}$ & References $^{\mathrm{b}}$ \\
\hline $\begin{array}{l}\text { Manitou Forest Observatory, } \\
\text { Colorado }\end{array}$ & $\begin{array}{l}39.1006^{\circ} \mathrm{N} \\
105.0942^{\circ} \mathrm{W}\end{array}$ & Pine Woodland & Pinus ponderosa & 1.5 & Kim et al. (2013) \\
\hline $\begin{array}{l}\text { Niwot Ridge, AmeriFlux, } \\
\text { Colorado }\end{array}$ & $\begin{array}{l}40.0329^{\circ} \mathrm{N} \\
105.5464^{\circ} \mathrm{W}\end{array}$ & Subalpine Forest & Pinus contorta, Abies lasiocarpa, Pieca engelmannii & 4.2 & $\begin{array}{l}\text { Monson et al. } \\
\text { (2010) }\end{array}$ \\
\hline $\begin{array}{l}\text { Deer Canyon Preserve, New } \\
\text { Mexico }\end{array}$ & $\begin{array}{l}34.4385^{\circ} \mathrm{N} \\
106.2377^{\circ} \mathrm{W}\end{array}$ & $\begin{array}{l}\text { Pinyon-Juniper } \\
\text { Forest }\end{array}$ & Pinus edulis, Juniperus monosperma, Bouteloua gracilis & 1.5 & $\begin{array}{l}\text { Krofcheck et al. } \\
\text { (2014) }\end{array}$ \\
\hline $\begin{array}{l}\text { Taihuyuan, Zhejiang province, } \\
\text { China }\end{array}$ & $\begin{array}{l}30.3000^{\circ} \mathrm{N} \\
119.5666^{\circ} \mathrm{E}\end{array}$ & $\begin{array}{l}\text { Subtropical Lei } \\
\text { Bamboo Forest }\end{array}$ & Phyllostachys violascens & 5.0 & Bai et al. (2016) \\
\hline $\begin{array}{l}\text { Qianyanzhou, Jiangxi province, } \\
\text { China }\end{array}$ & $\begin{array}{l}26.7466^{\circ} \mathrm{N} \\
115.6672^{\circ} \mathrm{E}\end{array}$ & $\begin{array}{l}\text { Subtropical Pine } \\
\text { Forest }\end{array}$ & Pinus massoniana, Pinus elliottii, Cunninghamia lanceolate & 6.8 & Bai et al. (2017) \\
\hline $\begin{array}{l}\text { MOFlux (Baskett Wildfire } \\
\text { Refuge), Missouri }\end{array}$ & $\begin{array}{l}38.7441^{\circ} \mathrm{N} \\
92.2000^{\circ} \mathrm{W}\end{array}$ & $\begin{array}{l}\text { Deciduous Oak } \\
\text { Forest }\end{array}$ & $\begin{array}{l}\text { Quercus alba L., Q. velutina Lam, Carya ovata, Acer saccharum Marsh., } \\
\text { Juniperus virginiana L. }\end{array}$ & 3.7 & Gu et al. (2016) \\
\hline PROPHET Station, Michigan & $\begin{array}{l}45.5667^{\circ} \mathrm{N} \\
84.7833^{\circ} \mathrm{W}\end{array}$ & $\begin{array}{l}\text { Mixed Deciduous } \\
\text { Forest }\end{array}$ & $\begin{array}{l}\text { Populus grandidentata, Populus tremuloides, Quercus rubra, Fagus } \\
\text { grandifolia, Acer rubrum, Pinus strobus }\end{array}$ & 3.7 & $\begin{array}{l}\text { Carroll et al. } \\
\text { (2001) }\end{array}$ \\
\hline $\begin{array}{l}\text { Changbai Mountain Forest } \\
\text { Research Station, China }\end{array}$ & $\begin{array}{l}42.4000^{\circ} \mathrm{N} \\
128.1000^{\circ} \mathrm{E}\end{array}$ & $\begin{array}{l}\text { Mixed Deciduous } \\
\text { Forest }\end{array}$ & $\begin{array}{l}\text { Pinus koraiensis, Tilia amurensis, Tilia mandshurica, Quercus } \\
\text { mongolica, Fraxinus mandshurica, Acer mono, Acer mandshurica }\end{array}$ & 5.5 & Bai et al. (2015) \\
\hline $\begin{array}{l}\text { Guyaflux site (GF-Guy), French } \\
\text { Guiana }\end{array}$ & $\begin{array}{l}5.2787^{\circ} \mathrm{N} \\
52.92486^{\circ} \mathrm{W}\end{array}$ & Tropical Rainforest & Caesalpiniaceae facies & $7.0^{c}$ & $\begin{array}{l}\text { Bonal et al. } \\
\text { (2008) }\end{array}$ \\
\hline
\end{tabular}

${ }^{\mathrm{a}} \mathrm{LAI}=$ Leaf area index $\left(\mathrm{m}^{2}\right.$ leaf area $/ \mathrm{m}^{2}$ ground area).

${ }^{b}$ References with a more detailed site description.

c Plant area index (PAI) is reported here instead of LAI. 
MOFlux experimental tower (refer to Table 1 for site details). The MOFlux site was chosen due to the high density of oaks which produce large emissions of isoprene (Potosnak et al., 2014). EC measurements of isoprene were made at $\sim 8-12 \mathrm{~m}$ above the top of the canopy, approximately $2 \mathrm{~m}$ above the REA setup. A Teflon inlet line was positioned at the base of a sonic anemometer (Campbell Scientific, CSAT-3) and pumped at 10 LPM to the base of the tower where a Fast Isoprene Sensor (FIS, Hills Scientific) was located. FIS measures isoprene through the chemiluminescence produced by the reaction of isoprene with high concentrations of ozone. Its applicability to ecosystem flux measurements has been described previously by Guenther and Hills (1998) and is well-suited for isoprene flux measurements at this site due to the high emission fluxes and concentrations of isoprene and coincident low concentrations of known interfering compounds. At the Manitou Forest Observatory, flux measurements of the major BVOCs were performed with a Proton-transfer-reaction mass spectrometer (PTR-MS) using virtual disjunct eddy covariance (Karl et al., 2002). Air was aspirated through a Teflon inlet line from the base of the sonic anemometer (at $\mathrm{z}$ $=25.1 \mathrm{~m}$, Campbell Scientific, CSAT-3) to a trailer at the base of the tower at a flow rate of 35 LPM. This flow was subsampled into the PTR-MS (F $\sim 200 \mathrm{sccm}$ ) through a short Teflon line. The primary BVOC emissions from this site are 2,3,2-methylbutenol (MBO) and a combination of several monoterpenes (Kaser et al., 2013a, 2013b). As there were analytical limitations on both PTR-MS (Kaser et al., 2013b) and the adsorption cartridges (Baker et al., 2001) with sampling of MBO, this intercomparison only focused on the monoterpene compounds $\left(\mathrm{C}_{10} \mathrm{H}_{16}\right)$. The sum of monoterpenes was measured at both the parent ion $(\mathrm{m} / \mathrm{z}=$ $137)$ and the major ion fragment $(\mathrm{m} / \mathrm{z}=81)$ in the PTR-MS (Sarkar et al., 2016). The REA sampler and anemometer were also placed at $25.1 \mathrm{~m}$ but directed perpendicular to the CSAT-3 anemometer to the south (the predominant wind direction).

\section{Results and discussion}

\subsection{Anemometer comparisons}

A common concern in the application of the REA technique is the potential biases in the mean vertical wind velocity $(\bar{w})$. Due to either sloping or complex topography and canopies or from sensor misalignment, it is typically found that 3-dimensional rotation of the wind velocities is necessary to align the vertical wind velocity perpendicular to the mean horizontal flow (e.g. $\bar{w} \sim 0$ ). This is typically done in postprocessing of eddy covariance fluxes. However, for REA sampling, decisions must be made in real-time. As mentioned above, it is possible to implement coordinate rotation into our REA based on long-term mean streamlines (methods such as the planar fit, (Wilczak et al., 2001), but for typical shorter deployments, it is necessary to forego this rotation and merely use the coordinate frame of the anemometer with some correction for consistent offsets in the mean vertical wind velocity. Therefore, it is necessary to determine how much error this introduces into the derived REA fluxes.

Fig. 2 shows the comparisons of the kinematic heat flux ( $w^{\prime} T^{\prime}$ ) and $\sigma_{w}$ calculated from the REA relative to an independent sonic anemometer (Campbell Scientific, CSAT-3) at the Manitou Experimental Forest site. Quantities from the independent anemometer were rotated using the planar fit method (Wilczak et al., 2001) prior to computing turbulent parameters, whereas values from the REA are essentially unrotated. As seen in the figure, the slopes for these two comparisons are close to unity ( 0.95 for $\sigma_{w}$ and 1.06 for $w^{\prime} T^{\prime}$ ), suggesting only a small bias caused by the lack of coordinate rotation. The small error is further demonstrated by the comparisons of the $b$-coefficients derived from the two anemometers. The CSAT-3 $b$-coefficients (and $\sigma_{w}, \bar{w}$ ) were derived from rotated time series, whereas REA b-coefficients were derived from conditionally sampling the unrotated vertical wind velocities and using $\sigma_{w}$ and $\bar{w}$ from the previous flux period (as described above). Fig. 2c
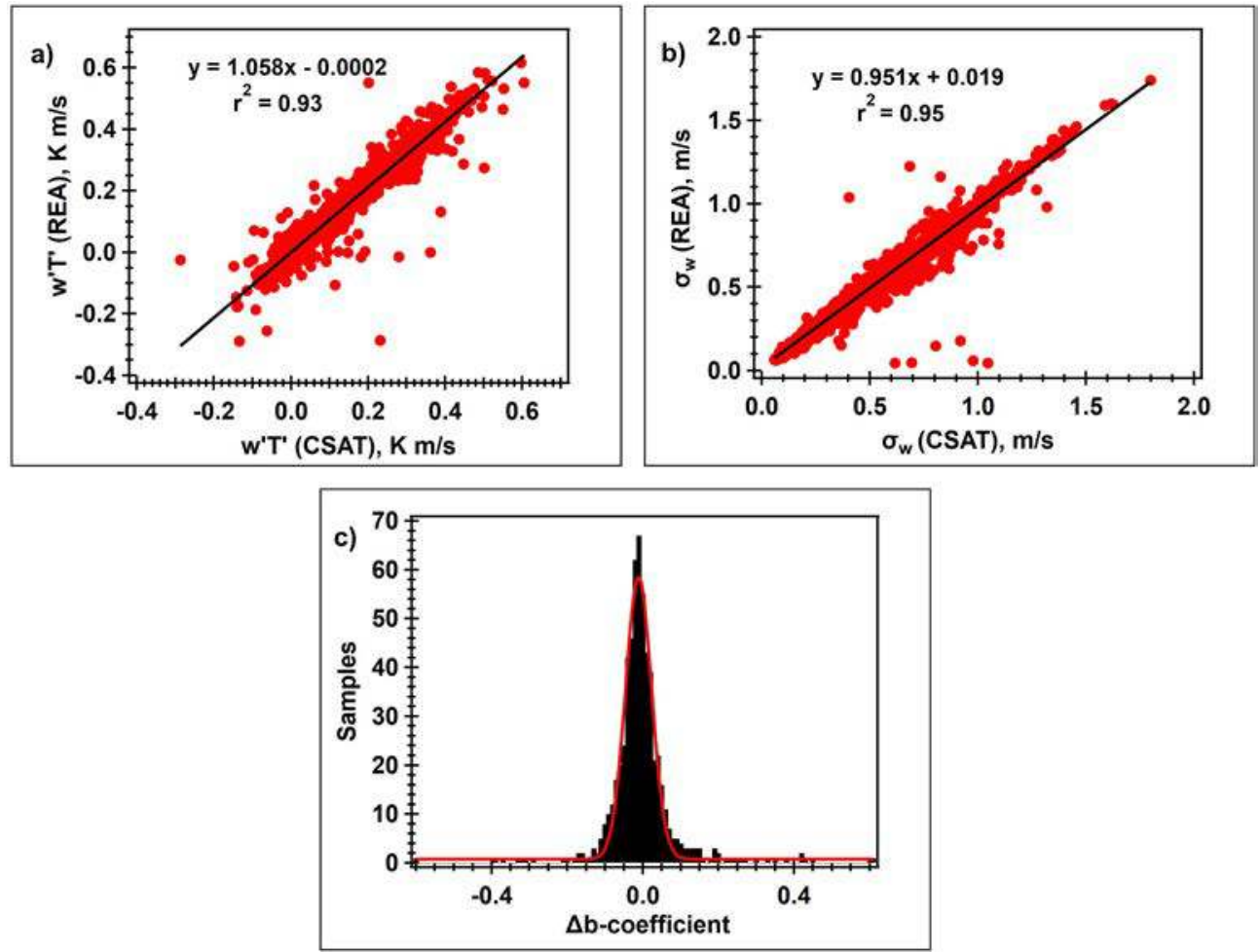

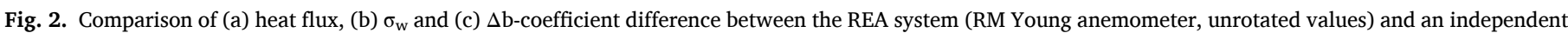

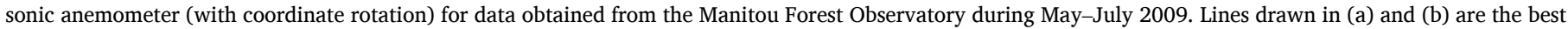
linear regression fit while the line drawn in (c) is the best fit to a Gaussian distribution. 
shows the frequency distribution of the difference between these two derived b-coefficients. As can be seen in the figure, the distribution is centered close to zero $(-0.011)$ with a $1 \sigma$ width of 0.035 (with 599 flux periods). From these comparisons, we conservatively estimate $<10 \%$ uncertainty at this site, associated with the raw unrotated vertical winds. The magnitude of this uncertainty likely depends upon the anemometer orientation relative to the underlying local topography and will be slightly different from site to site.

Apart from the turbulence variables, it is critical to verify that there is no cross-sampling between the up and down reservoirs and to obtain the correct sample volume that is collected on each cartridge. In fact, due to the concentration difference that must be computed in Eqn. (1), precision of the concentration is often the main source of uncertainty in a REA flux measurement. Therefore, this aspect of our REA sampler is critical to fully understand. Arnts et al. (2013) have discussed many of the sampling criteria necessary for REA systems such as valve speed, constant flow rate and accurate sample volume measurements.

We chose to use separate inlets for the up and down reservoirs such that, if the timing of the valves is correct, only "up" or "down" air enters the correct inlet, thus avoiding cross-sampling. This is essentially a “Type I" sampling system as designated by Arnts et al. (2013). This type of system does have an inherent timing offset as the wind velocity data that is received from the anemometer is collected during one sampling period and then used to set the valve status in the next. However, this lag of a single sample has been shown to be relatively unimportant over most canopies (Arnts et al., 2013) and is primarily an issue only for short vegetation and smooth landscapes. Sub-sampling from a single main inlet line can eliminate this lag, as described by Arnts et al. (2013). However, the lag time in the main inlet must be known very accurately and, although mass flow can be constantly maintained, the volumetric flow (and thus, the lag time) can change with environmental temperature and pressure without proper control. Since the goal of our system was to use very little power, we compromised by having separate up and down inlets and a constant 1-sample offset between wind data and valve control.

This type of REA sampling also results in some degree of pressure transients as the flow is stopped and started through the different sampling inlets. This was minimized by having a relatively small volume but with a significant flow conductance. The volume upstream of the segregating valves was essentially the volume of the adsorption cartridge $\left(\sim 2.5 \mathrm{~cm}^{3}\right)$. The cartridge was also the major flow impedance. By monitoring the signal from the mass flow controller at $10 \mathrm{~Hz}$, we observed flow transients were typically $<1 \%$ of the mean flow signal when commercially packed adsorption cartridges were used during typical REA sampling (e.g. valves were switching relative to changing vertical wind velocities). When cartridges packed within our lab were used, the magnitude of these transients increased to $2-3 \%$ of the mean flow rate, showing the non-uniformity of in-house packed cartridges. Therefore, we primarily used commercially packed cartridges for REA measurements to minimize flow transients to reduce the associated errors in the calculated sample volumes.

However, since the mass flowmeter response is only about $0.3 \mathrm{~s}$, very fast transients could be occurring which could affect the actual volume aspirated through the adsorption cartridge which would not be detected. Therefore, we also tested our sampler by introducing a VOC standard (isoprene and camphene) across all inlets. Valve control was either via the sonic anemometer (positioned on a mast on the roof of a building) or by alternating between the up and down cartridge every $10 \mathrm{~s}$ (used as a control). Samples were analyzed on the thermal desorption GC/FID system and the peak areas for isoprene and camphene were compared between the up and down cartridges. Volumes calculated from the mass flowmeter $\left(\mathrm{V}_{\text {flow }}\right)$ were then compared to those computed from the observed peak areas and known mixing ratios in our gas mixture $\left(\mathrm{V}_{\text {std }}\right)$. Fig. 3a shows a plot of $\mathrm{V}_{\text {flow }} / \mathrm{V}_{\text {std }}$ versus the valve switching frequency, known as the eddy reversal frequency (Baker et al., 1992). The valve switching frequency is typically between 0.5 and $3 \mathrm{~Hz}$ and is related to
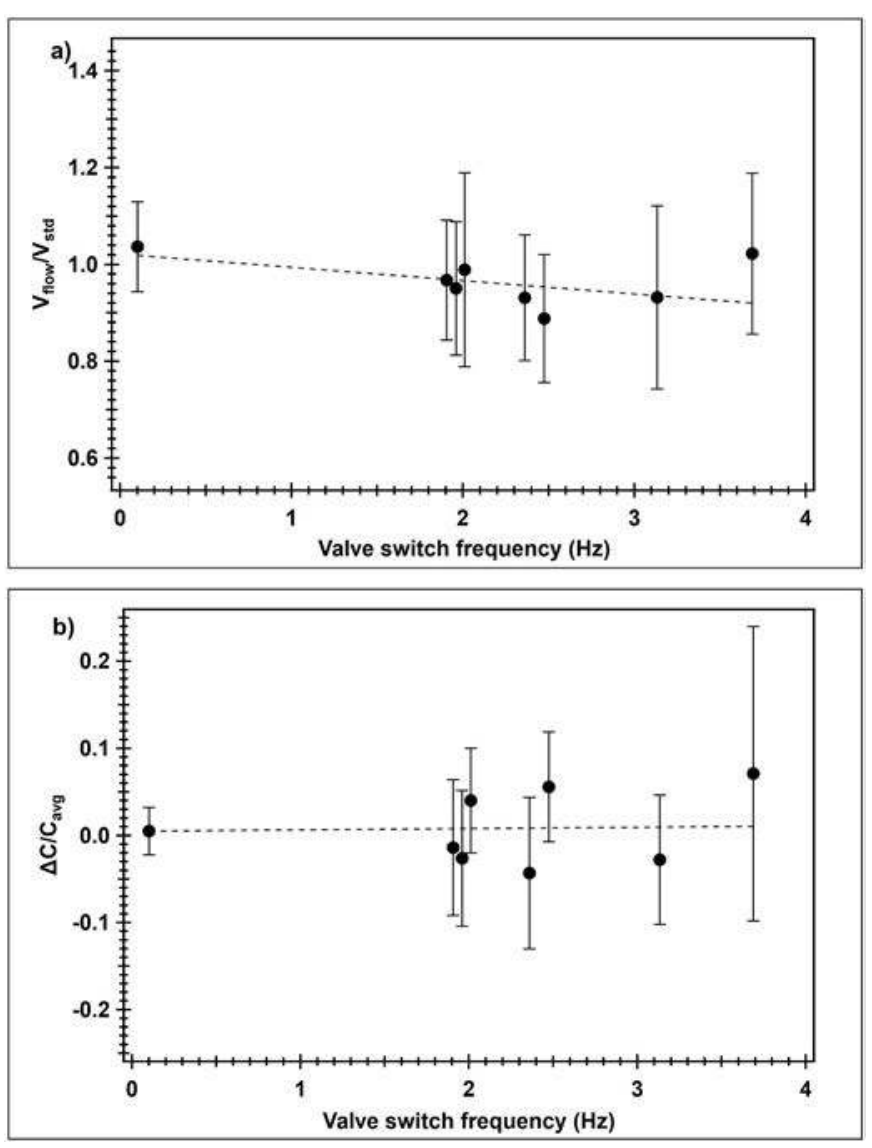

Fig. 3. Plots of a) $\mathrm{V}_{\text {flow }} / \mathrm{V}_{\text {std }}$ vs valve switching frequency and b) $\Delta C / C_{\text {avg }}$ vs valve switching frequency. Each point represents the average of 3 flux runs of $10 \mathrm{~min}$. For volumes, this represents a total of 6 measurements, whereas for $\Delta \mathrm{C} / \mathrm{C}_{\mathrm{avg}}$ this represents only 3 measurements. The error bars represent $1 \sigma$ of the data.

the degree of atmospheric turbulence. As can be seen in the figure, $\mathrm{V}_{\text {flow }} / \mathrm{V}_{\text {std }}$ typically averages around unity with a standard deviation (from six measurements) between $\pm 8-15 \%$. This $8-15 \%$ variability is also observed when the up and down valves are alternatively switched at a set frequency of $0.1 \mathrm{~Hz}$ (also shown in Fig. 3). Thus, this appears to be the uncertainty involved in the analysis of the adsorption cartridges as opposed to the errors in the volume calculations using the mass flow controller.

This $8-15 \%$ variability is also evident when plotting the percent difference $\left(\Delta \mathrm{C} / \mathrm{C}_{\mathrm{avg}}\right)$ as a function of the valve switching frequency (Fig. 3b). This allows us to estimate the concentration differences that this sampling system is able to measure and, thus, estimate the detection limit of fluxes and associated errors for this REA system. Assuming a minimum of $\Delta \mathrm{C} / \mathrm{C}_{\mathrm{avg}}$ of $>0.30$ is required and a typical $b$-coefficient of 0.4 (with deadband sampling) and $\sigma_{w}$ ranging from 0.2 to $1.4 \mathrm{~m} / \mathrm{s}$, Eqn. (1) predicts emission velocities $\left(\mathrm{F} / \mathrm{C}_{\mathrm{avg}}\right)>2.4-17 \mathrm{~cm} / \mathrm{s}$ are measurable with this REA system. Emission velocities of typical biogenics, such as isoprene and monoterpenes observed as the dominant BVOC at the sites compiled in Table 2, tend to range from 10 to $40 \mathrm{~cm} / \mathrm{s}$, thus, this system is capable of measuring fluxes of the major emitting compounds from these ecosystems at most times. However, compounds with relatively lower emission rates or VOCs that deposit to the ecosystem (which typically have velocities $<5 \mathrm{~cm} / \mathrm{s}$ ) will not be measurable with the measurement precision of the TD-GC-FID/MSD used here. The error on a single REA flux measurement will also include contributions from statistical sampling error, which is often about $10-15 \%$ for typical 30 -min flux periods in a convective surface layer (Lenschow, 1995).

Finally, the REA was compared to eddy covariance 
Table 2

Average fluxes measured with the portable REA at the nine sites described in Table 1.

\begin{tabular}{|c|c|c|c|c|}
\hline $\begin{array}{l}\text { Measurement } \\
\text { Site }\end{array}$ & $\begin{array}{l}\text { Major } \\
\text { compounds } \\
\text { emitted }\end{array}$ & $\begin{array}{l}\text { Average } \\
\text { Flux }^{\mathrm{a}}(\mathrm{mg} \\
\left.\mathrm{m}^{-2} \mathrm{~h}^{-1}\right)\end{array}$ & $\begin{array}{l}\text { Average } \\
\text { Temperature } \\
\left({ }^{\circ} \mathrm{C}\right)\end{array}$ & Reference \\
\hline $\begin{array}{l}\text { Manitou Forest } \\
\text { Observatory, } \\
\text { Colorado }\end{array}$ & $\begin{array}{l}2,3,2- \\
\text { methylbutenol } \\
\alpha \text {-pinene } \\
\beta \text {-pinene } \\
\Delta^{3} \text {-carene d- } \\
\text { Limonene }\end{array}$ & $\begin{array}{l}3.48(74) \\
0.23 \\
0.22 \\
0.20 \\
0.05\end{array}$ & 20.6 & This study \\
\hline $\begin{array}{c}\text { Niwot Ridge, } \\
\text { AmeriFlux, } \\
\text { Colorado }\end{array}$ & $\begin{array}{l}2,3,2- \\
\text { methylbutenol } \\
\alpha \text {-pinene } \\
\text { camphene } \\
\beta \text {-pinene d- } \\
\text { Limonene }\end{array}$ & $\begin{array}{l}0.73(55) \\
0.12 \\
0.08 \\
0.14 \\
0.17\end{array}$ & 11.5 & This study \\
\hline $\begin{array}{l}\text { Deer Canyon } \\
\text { Preserve, New } \\
\text { Mexico }\end{array}$ & $\begin{array}{l}\alpha \text {-pinene } \\
\text { Camphene }\end{array}$ & $\begin{array}{l}0.32(28) \\
0.02\end{array}$ & 23.1 & This study \\
\hline $\begin{array}{l}\text { Taihuyuan, } \\
\text { Zhejiang } \\
\text { province, } \\
\text { China }\end{array}$ & $\begin{array}{l}\text { Isoprene } \\
\alpha \text {-pinene }\end{array}$ & $\begin{array}{l}0.95(115) \\
0.01\end{array}$ & 16.0 & $\begin{array}{l}\text { Bai et al. } \\
(2016)\end{array}$ \\
\hline $\begin{array}{l}\text { Qianyanzhou, } \\
\text { Jiangxi } \\
\text { province, } \\
\text { China }\end{array}$ & $\begin{array}{l}\text { Isoprene } \\
\alpha \text {-pinene } \\
\text { Camphene } \\
\beta \text {-pinene d- } \\
\text { Limonene }\end{array}$ & $\begin{array}{l}0.15(451) \\
0.31 \\
0.05 \\
0.09 \\
0.08\end{array}$ & 17.9 & $\begin{array}{l}\text { Bai et al. } \\
\text { (2017) }\end{array}$ \\
\hline $\begin{array}{l}\text { MOFlux (Baskett } \\
\text { Wildfire } \\
\text { Refuge), } \\
\text { Missouri }\end{array}$ & $\begin{array}{l}\text { Isoprene } \\
\alpha \text {-pinene }\end{array}$ & $\begin{array}{l}9.56(27) \\
0.03\end{array}$ & 22.5 & This study \\
\hline $\begin{array}{l}\text { PROPHET } \\
\text { Station, } \\
\text { Michigan }\end{array}$ & $\begin{array}{l}\text { Isoprene } \\
\alpha \text {-pinene } \\
\beta \text {-pinene d- } \\
\text { Limonene }\end{array}$ & $\begin{array}{l}1.63(39) \\
0.09 \\
0.04 \\
0.07\end{array}$ & 20.6 & This study \\
\hline $\begin{array}{l}\text { Changbai } \\
\text { Mountain } \\
\text { Forest } \\
\text { Research } \\
\text { Station, China }\end{array}$ & $\begin{array}{l}\text { Isoprene } \\
\alpha \text {-pinene } \\
\beta \text {-pinene d- } \\
\text { Limonene }\end{array}$ & $\begin{array}{l}0.80(87) \\
0.06 \\
0.01 \\
0.04\end{array}$ & 21.4 & $\begin{array}{l}\text { Bai et al. } \\
(2015)\end{array}$ \\
\hline $\begin{array}{l}\text { Guyaflux site } \\
\text { (GF-Guy), } \\
\text { French Guiana }\end{array}$ & $\begin{array}{l}\text { Isoprene } \\
\alpha \text {-pinene }\end{array}$ & $\begin{array}{l}1.6(136) \\
0.16\end{array}$ & 27.7 & This study \\
\hline
\end{tabular}

a Total number of flux measurements given in parenthesis.

measurements of VOCs for two short periods at two different sites. One inter-comparison was carried out at the MOFlux tower site in central Missouri and focused solely on isoprene. EC measurements were conducted using a Fast Isoprene Sensor (FIS, Hills Scientific) which has been shown to be adequate for EC measurements over forests with strong isoprene fluxes (Guenther and Hills, 1998). The FIS at the MOFlux site was part of a long-term seasonal study which indicated very strong isoprene fluxes at this site due to high density of oaks. Fig. 4 shows a comparison of the REA isoprene fluxes with those derived from the FIS. In general, the REA fluxes show a higher degree of scatter due to the measurement variability discussed above. There was a $1.8 \mathrm{mg} \mathrm{m}^{-2} \mathrm{~h}^{-1}$ bias in the REA fluxes as compared to the EC measurements (the intercept in Fig. 4); the source of this bias is unknown. However, the REA samples were within about $20 \%$ of the EC values for the typical fluxes ( $10 \mathrm{mg} \mathrm{m}^{-2} \mathrm{~h}^{-1}$ ) at this site. The inter-comparison with the PTR-MS technique at the Manitou Experimental Forest is discussed in the context of a longer-term study described in Section 3.3.

\subsection{Landscape average isoprene and monoterpene fluxes from nine forest ecosystems}

Table 2 includes the major BVOCs observed at nine forest ecosystems (coniferous, mixed deciduous and tropical rainforest) and the average measured emission fluxes. 2,3,2-methylbutenol (2,3,2-MBO) dominated

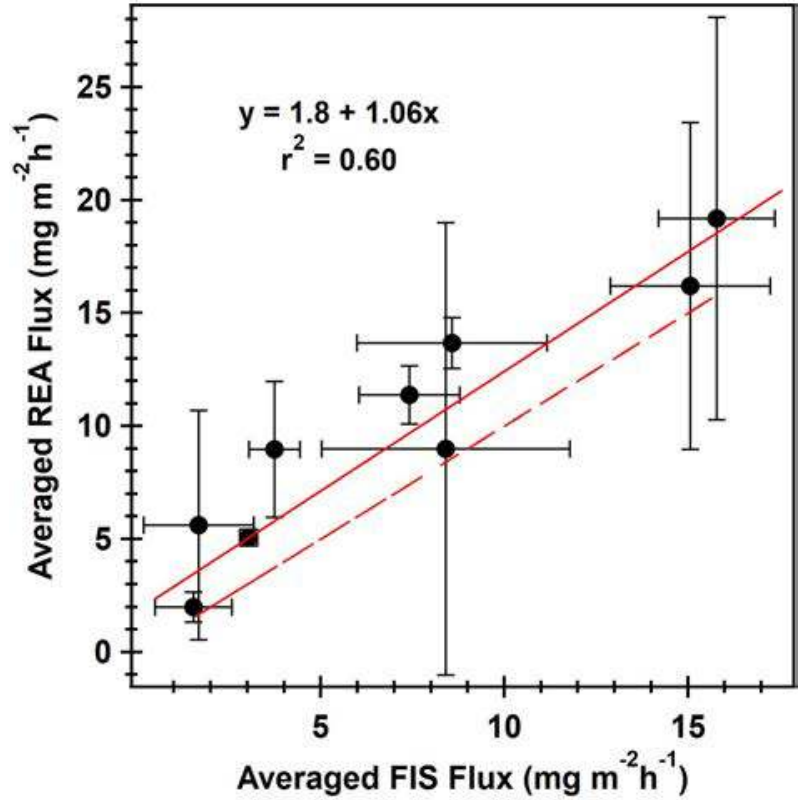

Fig. 4. Comparison between the REA-derived fluxes for isoprene and those from the eddy covariance measurements with the FIS. Points are the average of three consecutive flux measurements and error bars give the $1 \sigma$ variability for each technique. The dashed line represents the 1:1 line. Data is from the MOFlux site from 31 August - 2 September 2011.

the measured BVOC fluxes (average flux $\sim 3.48 \mathrm{mg} \mathrm{m}^{-2} \mathrm{~h}^{-1}$ ) at the Manitou Forest Observatory, Colorado that is primarily a pine woodland ecosystem dominated by Pinus ponderosa (Kim et al., 2013). In addition to 2,3,2-MBO, significant $\alpha$-pinene, $\beta$-pinene, $\Delta^{3}$-carene and d-Limonene emissions were also observed at this site. Dominance of 2,3,2-MBO and monoterpene emissions at the Manitou Forest Observatory site was previously reported by Ortega et al. (2014). A detailed discussion on the BVOC flux measurements using REA at this site is presented in section 3.3. At the Niwot Ridge site in Colorado, which is a subalpine coniferous forest, 2,3,2-MBO fluxes were the highest (average $\sim 0.73 \mathrm{mg} \mathrm{m}^{-2} \mathrm{~h}^{-1}$ ) among all the major species measured including $\alpha$-pinene, $\beta$-pinene, camphene and d-Limonene. 2,3,2-MBO fluxes were previously reported from the Niwot Ridge site by Karl et al. (2002) using the PTR-MS virtual disjunct eddy covariance (DEC) method. Those previous midday average values ranged from $\sim 1.0$ to $1.5 \mathrm{mg} \mathrm{m}^{-2} \mathrm{~h}^{-1}$, in reasonable agreement with the values reported here. Emissions of $\alpha$-pinene and camphene (average fluxes $\sim 0.32 \mathrm{mg} \mathrm{m}^{-2} \mathrm{~h}^{-1}$ and $\sim 0.02 \mathrm{mg} \mathrm{m}^{-2} \mathrm{~h}^{-1}$ ) were observed from the pinyon-juniper forest at the Deer Canyon Preserve in New Mexico. $\alpha$-pinene fluxes measured at this site were higher than any of the other sites reported in this study. Seasonal variations of BVOC fluxes at two forest ecosystems in China, namely the subtropical Lei bamboo plantation site at Taihuyuan and the subtropical pine forest site at Qianyanzhou, were measured using the REA system and the observations have previously been described in more detail (Bai et al., 2016, 2017). BVOC emissions at the Taihuyuan site were dominated by isoprene $\left(\sim 0.95 \mathrm{mg} \mathrm{m}^{-2} \mathrm{~h}^{-1}\right)$ while the Qianyanzhou site was dominated by $\alpha$-pinene emissions $\left(\sim 0.31 \mathrm{mg} \mathrm{m}^{-2} \mathrm{~h}^{-1}\right)$, due to the high abundance of the Pinus species at this site, along with significant isoprene emission $\left(\sim 0.15 \mathrm{mg} \mathrm{m}^{-2} \mathrm{~h}^{-1}\right)$ from other vegetation.

Isoprene dominated the measured BVOC fluxes at the MOFlux site in Missouri with an average flux of $\sim 9.5 \mathrm{mg} \mathrm{m}^{-2} \mathrm{~h}^{-1}$. MOFlux site is a mixed deciduous forest dominated by Quercus alba L., Q. velutina Lam, Carya ovata, Acer saccharum Marsh., Juniperus virginiana L. (Gu et al., 2016). Isoprene fluxes measured using REA at the MOFlux site were at least $\sim 6$ times higher than the isoprene fluxes measured from all the other sites reported in this study. Apart from isoprene, some $\alpha$-pinene was also emitted at this site. Previous field measurements at the MOFlux 
site also reported similar levels of isoprene emissions (Potosnak et al., 2014; Seco et al., 2015). The mixed deciduous forest sites at the PROPHET Station in Michigan and the Changbai Mountain Forest Research Station in China emitted isoprene, $\alpha$-pinene, $\beta$-pinene and D-Limonene. The BVOC fluxes measured at the PROPHET site were higher than that of the Changbai site, primarily due to the high isoprene at the PROPHET site. For example, the average isoprene flux at PROPHET $\left(\sim 1.6 \mathrm{mg} \mathrm{m}^{-2} \mathrm{~h}^{-1}\right)$ was twice the average isoprene flux at Changbai $\left(\sim 0.8 \mathrm{mg} \mathrm{m}^{-2} \mathrm{~h}^{-1}\right)$. Other studies have reported higher isoprene fluxes at the PROPHET site (Westberg et al., 2001; Apel et al., 2002) compared to our study. The seasonal and interannual variations of BVOCs measured using REA at the Changbai site was previously reported by Bai et al. (2015). Isoprene and $\alpha$-pinene emissions (average fluxes $\sim 1.6 \mathrm{mg} \mathrm{m}^{-2} \mathrm{~h}^{-1}$ and $\sim 0.16 \mathrm{mg} \mathrm{m}^{-2} \mathrm{~h}^{-1}$, respectively) were the primary fluxes observed at the tropical rainforest site in French Guiana (Guyaflux site; GF-Guy). The diurnal, seasonal and interannual variations of isoprene and $\alpha$-pinene fluxes at this site are discussed later in section 3.4. For all nine BVOC flux measurement sites reported in this study, $\alpha$-pinene was always observed to be one of the highest contributors to monoterpenes even across this wide range of different forest ecosystems.

Table 3 shows calculated emission factors (EFs) for isoprene and total monoterpenes for all the nine measurement sites. For the three sites in China, standard conditions (LAI $=5 \mathrm{~m}^{2} \mathrm{~m}^{-2}$, temperature $=30^{\circ} \mathrm{C}$ and $\mathrm{PAR}=1500 \mu \mathrm{mol} \mathrm{m}^{-2} \mathrm{~s}^{-1}$ ) were chosen, while EFs for the other six sites were adjusted only for measured temperature and LAI in MEGAN2.1 model, due to the unavailability of PAR data.

\subsection{Diurnal and seasonal variations of monoterpenes fluxes from two temperate needleleaf forests}

Monoterpene (MT) fluxes were measured at the Manitou Forest Observatory during the spring of 2009 and the summer of 2011. Fig. 5 shows the timeseries from 2009 to 2011, showing the total MT flux derived from PTR-MS along with speciated fluxes of the monoterpenes calculated from REA. As can be seen from the figure, the sum of the REA MT fluxes agrees quite well (within $\pm 10 \%$ ) with those derived from PTR-MS. As a test, we also looked at CFC113 (trifluoromethane) at m/z $=151$ desorbed from the cartridges. As there should be no flux for this species (there are no known biogenic sources or sinks), the peak area normalized by the volume $\left(S_{n}\right)$ should be the same in both up and down sample. From the 15 flux measurements made, $\left(S_{n_{\text {up }}}-S_{n_{\text {down }}}\right) / S_{n_{\text {avg }}}$ was $0.02 \pm 0.12$, consistent with a zero flux and the limits of measurable emission velocities estimated in the previous section.

Although this REA system was not designed for continuous measurements, it is possible to conduct weekly flux measurements to provide a snapshot of how fluxes can vary on a seasonal time scale. This was

Table 3

Isoprene and monoterpene emission factors (EFs) for the nine REA measurement sites described in Table 1.

\begin{tabular}{lll}
\hline Measurement Sites & \multicolumn{2}{l}{ Emission Factors (mg m } \\
& \multicolumn{2}{l}{$\left.\mathrm{h}^{-1}\right)^{\mathrm{a}}$} \\
\cline { 2 - 3 } & Isoprene & Monoterpenes \\
\hline Manitou Forest Observatory, Colorado & - & 8.23 \\
Niwot Ridge, AmeriFlux, Colorado & - & 4.95 \\
Deer Canyon Preserve, New Mexico & - & 2.60 \\
Taihuyuan, Zhejiang province, China & 4.30 & 0.13 \\
Qianyanzhou, Jiangxi province, China & 3.30 & 0.01 \\
MOFlux (Baskett Wildfire Refuge), Missouri & 29.82 & 0.06 \\
PROPHET Station, Michigan & 7.11 & 0.82 \\
Changbai Mountain Forest Research Station, China & 3.30 & 0.35 \\
Guyaflux site (GF-Guy), French Guiana & 1.91 & 0.17 \\
\hline
\end{tabular}

${ }^{\text {a }}$ EFs for the three sites in China were adjusted for standard LAI $\left(5 \mathrm{~m}^{2} \mathrm{~m}^{-2}\right)$, temperature $\left(30^{\circ} \mathrm{C}\right)$ and PAR $\left(1500 \mu \mathrm{mol} \mathrm{m} \mathrm{m}^{-2} \mathrm{~s}^{-1}\right)$ while EFs for the other six sites were adjusted only for temperature and LAI. undertaken at the Niwot Ridge flux tower in 2007. Fig. 6a shows a time series of weekly flux measurements (typically 2-3 consecutive flux periods during midday) of $\alpha$-pinene from the Niwot Ridge subalpine forest. Fluxes remained quite low until mid-June, when fluxes were suddenly enhanced for a period of about 2-3 weeks. This period coincided with new needle growth. The fluxes then lessened and were more variable over the remainder of the summer and into fall. The exception to this occurred on July 25 when two flux measurements were made following a severe hailstorm. Concentrations of all monoterpenes increased dramatically (partially due to a moderately stable boundary layer after the storm) and the fluxes were observed to be similar to the earlier peak during new growth. We assume that physical damage due to the hailstorm released monoterpenes from storage pools in the needles and branches which allowed for the increase in fluxes. Similar observations after a hailstorm were reported by Kaser et al. (2013a) from the Manitou Forest site. The Kaser et al. (2013a) study showed that these damage-related flux increases can be quite large and that these temporary enhancements in emissions could be nearly half of the annual sum.

Fig. $6 \mathrm{~b}$ shows these same flux measurements plotted vs. ambient temperature. This plot also includes data taken two years later during the late summer-fall (mid-August until October 2009). Data from both years are in good agreement and the fluxes generally tend to follow a simple exponential temperature curve. This is in reasonable agreement with the MEGAN2.1 model (Guenther et al., 2006) estimates for this ecosystem type. However, the period of new needle growth exhibits much higher fluxes than modeled by temperature alone, suggesting that other emission controls are important during this time period.

\subsection{Diurnal, seasonal and interannual variations of isoprene and $\alpha$-pinene fluxes from a tropical forest}

A second application of the REA system for relatively long-term studies was undertaken for a three-year period at a tropical forest site in French Guiana (Guyaflux site; GF-Guy). Previous short-term BVOC flux studies in tropical forest ecosystems show discrepancies between wet and dry season fluxes of BVOCs (primarily isoprene) with dry season fluxes being substantially larger (Barkley et al., 2009; Alves et al., 2016). Periodic REA measurements (using the same measurement system) have the potential for observing these longer-term seasonal and interannual variations. Midday REA fluxes of isoprene and $\alpha$-pinene were measured between the fall of 2009 (dry season 2009) and the fall of 2011 (dry season 2011). Flux measurements were typically performed between the hours of 10:00 and 16:00 local time (LT). Fig. 7a shows an example plot of the average midday diurnal flux for both isoprene and $\alpha$-pinene for a day during the dry season in 2009 (21 October 2009), both of which exhibited the expected midday peak around 13:00 local time, coinciding with a peak in the sensible heat flux (also shown in Fig. 7). Several previous studies have shown that isoprene flux is typically well-correlated with the sensible heat flux due to the light and temperature dependencies of isoprene emission (Rinne et al., 2002; Baker et al., 2005). Averaging the fluxes over different seasons (Fig. 7b) shows that there was a significant flux enhancement during the initial 2009 dry season for both isoprene $\left(\sim 4.3 \mathrm{mg} \mathrm{m}^{-2} \mathrm{~h}^{-1}\right)$ and $\alpha$-pinene $(\sim 0.33 \mathrm{mg}$ $\mathrm{m}^{-2} \mathrm{~h}^{-1}$ ). However, following this period, $\alpha$-pinene fluxes remained reasonably constant over the subsequent two-year period. Isoprene fluxes were more variable with average dry season fluxes that were higher than those in the wet season. However, the average isoprene flux during the 2010 wet season was comparable to those obtained during subsequent dry seasons.

Fig. 8 shows the average emission factors (EFs) for isoprene and $\alpha$-pinene during morning (09:00 - 11:00 LT), midday (11:00 - 13:00 LT) and afternoon (13:00 - 15:00 LT) for different seasons at the Guyaflux site. EFs were estimated as the ratio of the observed emissions to the estimated emission activity factors (EAFs) obtained from the MEGAN2.1 model (Guenther et al., 2012) using measured solar radiation and temperature. Generally, isoprene EFs showed an increasing trend from 


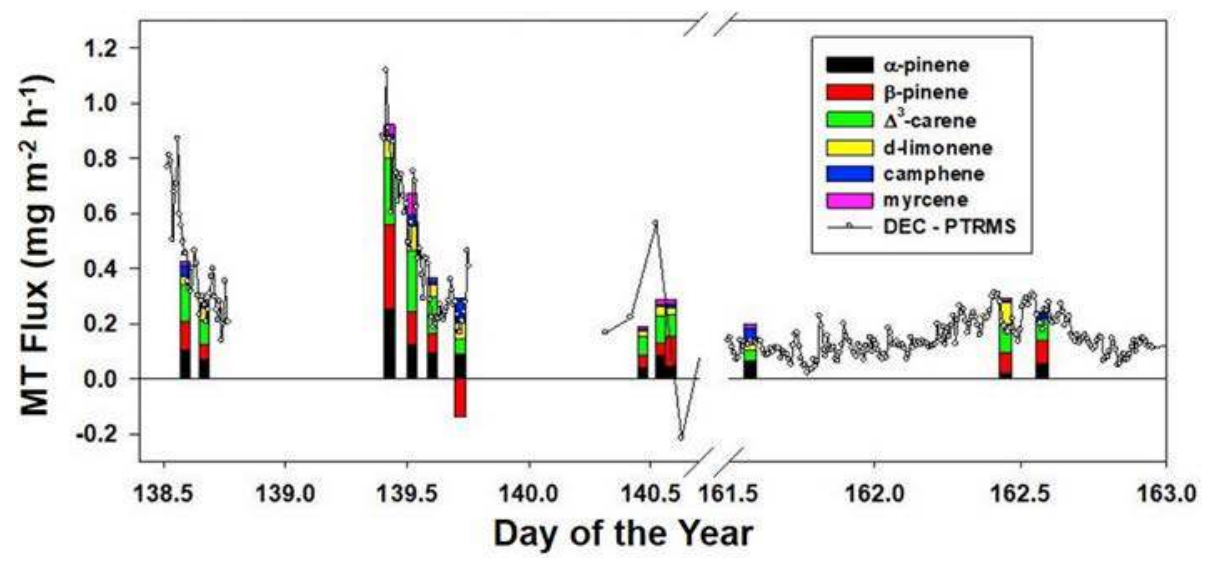

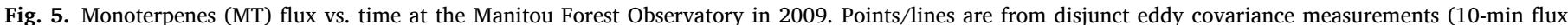

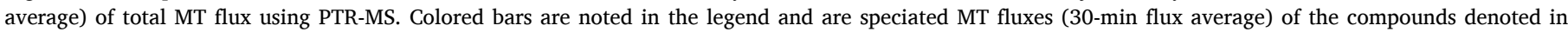
the legend.
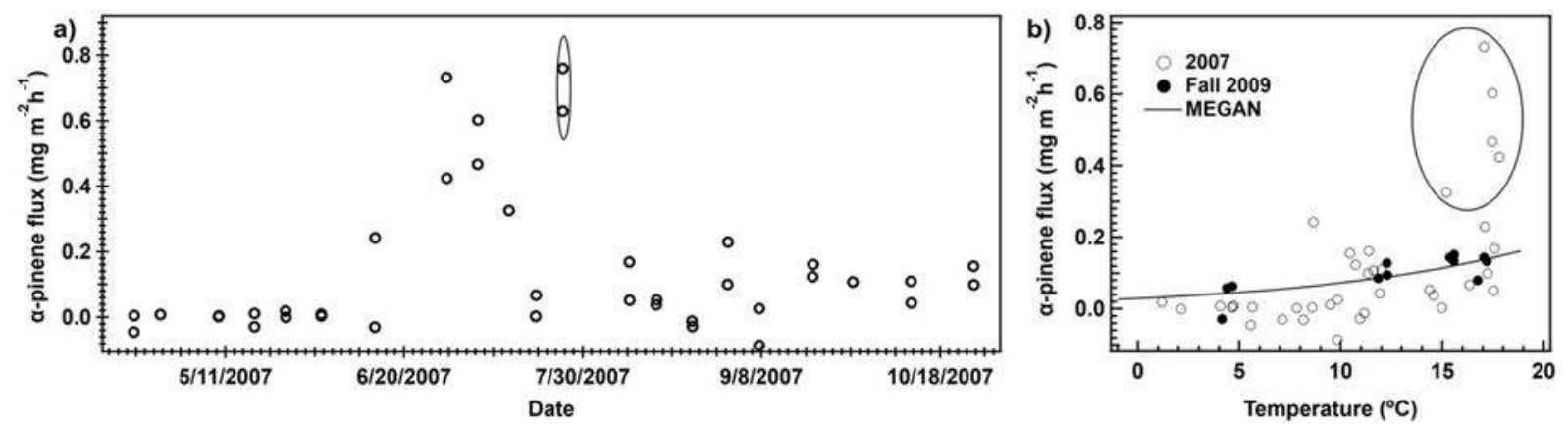

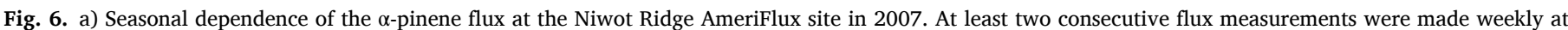

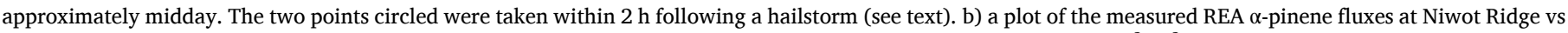

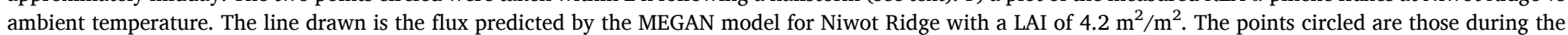
growth of new needles ( 9 June 2007-13 July 2007). Fluxes measured following the hailstorm on 25 July are omitted.
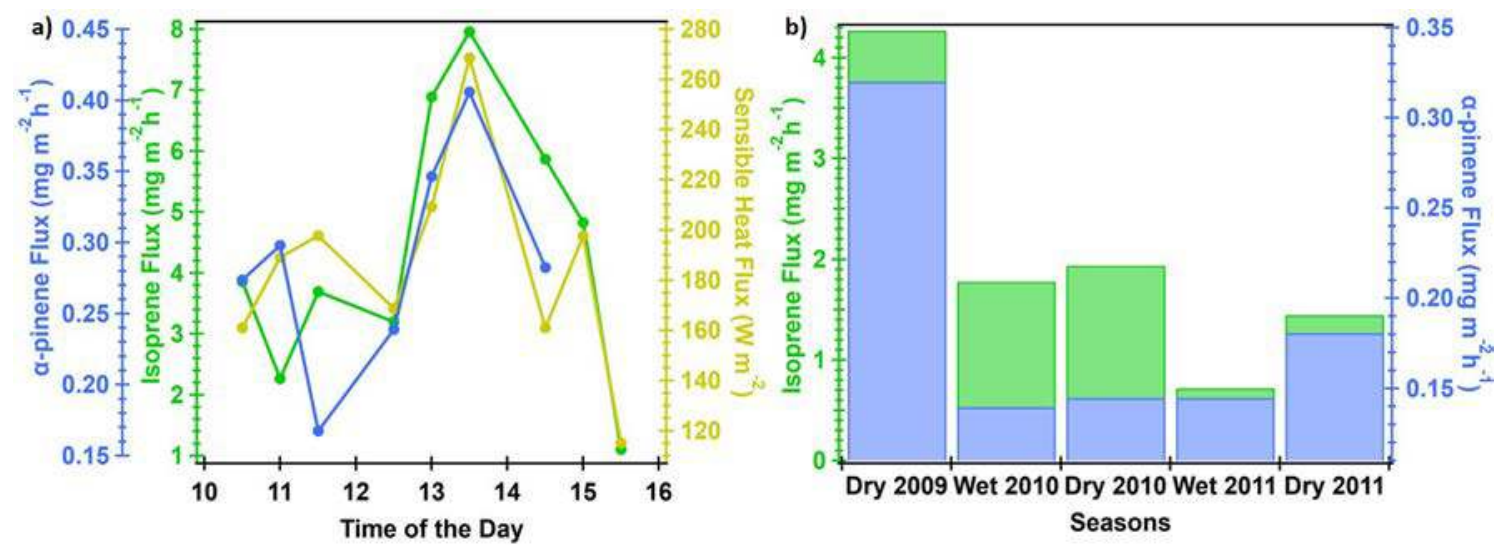

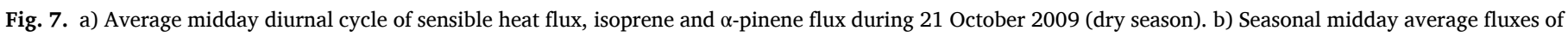
isoprene and $\alpha$-pinene. Data are from the Guyaflux site in French Guiana situated in a tropical forest.

morning till afternoon during all seasons while no such trend was observed for $\alpha$-pinene. In addition, isoprene EFs were relatively higher during the dry seasons as compared to the wet seasons. A decreasing trend can also be observed in isoprene EFs from 2009 to 2011. It is difficult to discern any seasonal trend in the EFs of $\alpha$-pinene. Although periodic REA measurements can observe large seasonal trends, discerning more fine-scale diurnal variability likely requires a larger number of measurements. This demonstrates the need for coupling the
REA system with an in-situ measurement system, such as an on-line GC, similar to that described by Schade and Goldstein (2001) for oxygenated VOC and by Rhew et al. (2017) for alkenes, could provide the necessary sampling rate to observe the shorter temporal trends.

\section{Conclusions}

BVOC fluxes were measured in nine forest ecosystems using a relaxed 

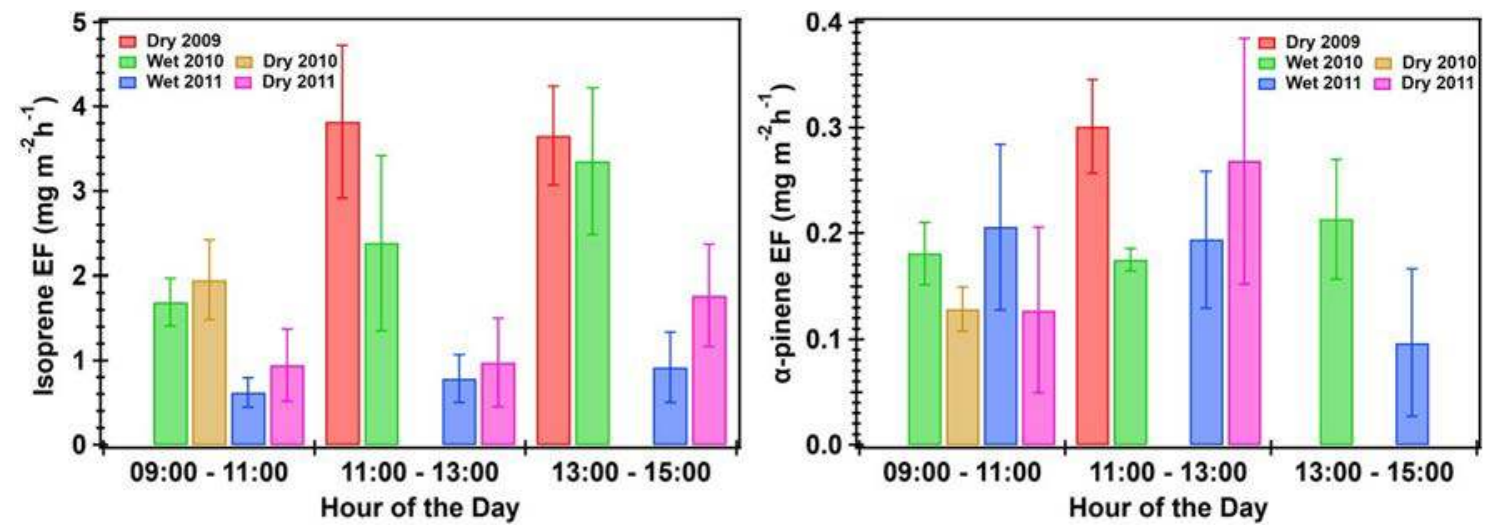

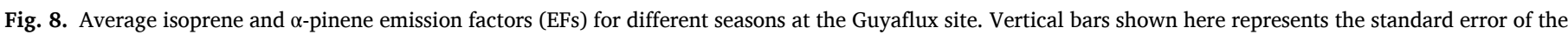
mean $\left(\frac{\sigma}{\sqrt{n}}\right)$. Data are shown for all periods for which total number of hourly average measurements (n) are $>1$.

eddy accumulation (REA) based sampling system. The advantages of this REA system are its low-cost, portability and simple operational procedure which allows easy deployment at remote locations in contrast to high sensitivity chemical ionization mass spectrometry instruments that are expensive, require more power and are not easily transported. A detailed description of the sampling setup, operational procedure and validation with eddy covariance direct BVOC flux measurements is provided in this manuscript. The minimum emission velocities $\left(\mathrm{F} / \mathrm{C}_{\mathrm{avg}}\right)$ that our REA system is capable of measuring were $>2.4-17 \mathrm{~cm} / \mathrm{s}$ which allows us to measure major BVOC fluxes such as isoprene and dominant monoterpenes for which emission velocities are typically at least 10-40 $\mathrm{cm} / \mathrm{s}$. Therefore, this REA setup was capable of investigating fluxes of major BVOCs emitted from the nine ecosystems reported in this study. However, the current measurement precision of this REA does not allow us to measure VOCs that are deposited to the ecosystem since typical deposition velocities are $<5 \mathrm{~cm} / \mathrm{s}$. Monoterpene fluxes measured by this REA system agreed quite well (within $\pm 10 \%$ ) with fluxes measured directly using PTR-MS eddy covariance measurements at the Manitou Forest site in Ponderosa pine woodland. An inter-comparison study of the REA system with eddy covariance measurements of isoprene using a Fast Isoprene Sensor (FIS) at the MOFlux tower site in a mixed broadleaf forest in central Missouri agreed reasonably well for moderate to high fluxes (within $20 \%$ but with a consistent bias as compared to the EC measurements) and with a higher degree of scatter for REA fluxes due to the measurement variability associated with the REA measurements.

BVOC measurements using the REA system were carried out between 06:00 - 18:30 (Local Time) at a flux averaging period of 30 mins to characterize midday fluxes at nine forested sites. These measurements confirmed the dominance of 2,3,2-methylbutenol (2,3,2-MBO) at both the Manitou Forest Observatory, dominated by MBO-emitting Pinus ponderosa (Ponderosa pine) trees, and the Niwot Ridge site, dominated by MBO-emitting Pinus contorta (lodgepole pine) along with spruce and fir trees. In addition to 2,3,2-MBO, $\alpha$-pinene, $\Delta^{3}$-carene, $\beta$-pinene and dLimonene emissions were also observed at the Manitou Forest Observatory. The MOFlux site in Missouri showed isoprene dominance (average flux of $\sim 9.5 \mathrm{mg} \mathrm{m}^{-2} \mathrm{~h}^{-1}$ ) while the Deer Canyon site was dominated by $\alpha$-pinene emissions (average flux $\sim 0.73 \mathrm{mg} \mathrm{m}^{-2} \mathrm{~h}^{-1}$ ). The PROPHET Station in Michigan and Changbai Mountain Forest Research Station in China, both of which are dominated by mixed deciduous forests, emitted significant isoprene along with some $\alpha$-pinene, $\beta$-pinene and d-Limonene. Isoprene $\left(\sim 0.95 \mathrm{mg} \mathrm{m}^{-2} \mathrm{~h}^{-1}\right)$ dominated the subtropical lei bamboo plantation site at Taihuyuan in China while the subtropical Pinus forest at Qianyanzhou in China was dominated by $\alpha$-pinene $\left(\sim 0.31 \mathrm{mg} \mathrm{m}^{-2} \mathrm{~h}^{-1}\right)$ along with significant isoprene $(\sim 0.15$ $\mathrm{mg} \mathrm{m}^{-2} \mathrm{~h}^{-1}$ ). $\alpha$-pinene was a dominant monoterpene at all nine forests reported in this study, irrespective of the type of the forest ecosystem.

BVOC measurements across different seasons during 2009-2011 showed isoprene emissions dominated at the Guyaflux site (GF-Guy) in French Guiana during all seasons. However, the off-line analysis of the REA system described here makes it difficult to obtain the large number of measurements required to investigate the processes controlling seasonal variability. The off-line system described here is suitable for investigating ecosystem average BVOC fluxes and short-term emission variations in the dominant BVOC fluxes from most forests, but the REA system should be coupled with an on-line GC analysis system for longer term measurements.

\section{CRediT authorship contribution statement}

Chinmoy Sarkar: Formal analysis, Visualization, Writing - original draft. Andrew Turnipseed: Conceptualization, Data curation, Formal analysis, Investigation, Methodology, Project administration, Software, Validation, Visualization, Writing - original draft. Stephen Shertz: Methodology, Software, Writing - review \& editing. Thomas Karl: Data curation, Investigation, Writing - review \& editing. Mark Potosnak: Resources, Data curation, Investigation, Writing - review \& editing. Jianhui Bai: Resources, Data curation, Investigation, Writing - review \& editing. Dominique Serça: Resources, Data curation, Investigation, Writing - review \& editing. Damien Bonal: Resources, Data curation, Investigation, Writing - review \& editing. Benoit Burban: Resources, Data curation, Investigation, Writing - review \& editing. Paula R.C. Lopes: Data curation, Investigation, Writing - review \& editing. Oscar Vega: Resources, Data curation, Investigation, Writing - review \& editing. Alex B. Guenther: Conceptualization, Data curation, Formal analysis, Funding acquisition, Investigation, Methodology, Project administration, Resources, Software, Supervision, Validation, Visualization, Writing - original draft.

\section{Declaration of competing interest}

The authors declare that they have no known competing financial interests or personal relationships that could have appeared to influence the work reported in this paper.

\section{Acknowledgements}

We would like to acknowledge the following people who allowed access and assisted us at the various research sites described in this work: 1) Sean Burns and Russell Monson - the Niwot Ridge AmeriFlux site; 2) Kevin Hosman, Stephen Pallardy and Lianhong Gu - the MOFlux site; 3) Mike Ryan and the US Forest Service - Manitou Forest Observatory; 4) Mary Anne Carroll and Steve Bertman - PROPHET site; 5) Marcy Litvak - Deer Canyon Preserve; 6) S. J. Han, J. H. Zhang, H. Xu, F. Y. Lin, D. Li, G. Z. Song, W. Yan - Changbai Mountain temperate forest; 
7) S. L., Li, S. Q. Yu, B. Wang - subtropical lei bamboo plantation site at Taihuyuan, and 8) H. M., Wang, F. T., Yang, Q. K., Li, G. Z., Liu, L. Huang, Y. G., Wang, S. Y., Yin, J. D., Zou, J. Z., Zhang, Y. F., Huang, G. L. Zhu - subtropical Pinus forest site at Qianyanzhou. Measurements at the site in French Guiana were carried out as part of the Guyaflux program which is supported by two French "investissement d'avenir" grants from the Agence Nationale de la Recherche (CEBA, ref ANR-10-LABX-25-01; ARBRE, ref. ANR-11-LABX-0002-01). Measurements in China were supported by the National Natural Science Foundation of China (NO. 41275137), ESA-MOST China Dragon Cooperation, Dragon4 project (ID 32771), and EU 7 framework program MarcoPolo (NO. 606953). The authors gratefully acknowledge assistance from Lisa Kaser for the PTRMS flux comparison measurements. M. P. acknowledges support from the National Science Foundation (NSF) for a Collaborative Research award entitled Biogenic Volatile Organic Compound Emissions from the Tundra and Arctic Atmospheric Chemistry (1025948). A. B. G. acknowledges support from the National Science Foundation (NSF) for a research award entitled Atmospheric Biogenic Organic Emissions: Missing Compounds and Unrepresented Processes (1643042). P. R. C. L. acknowledges support from a fellowship from the Brazilian government. The field measurements at all sites were supported by the National Center for Atmospheric Research (NCAR) which is sponsored by the National Science Foundation.

\section{Appendix A. Supplementary data}

Supplementary data to this article can be found online at https://doi. org/10.1016/j.atmosenv.2020.117764.

\section{References}

Alves, E.G., Jardine, K., Tota, J., Jardine, A., Yãnez-Serrano, A.M., Karl, T., Tavares, J., Nelson, B., Gu, D., Stavrakou, T., Martin, S., Artaxo, P., Manzi, A., Guenther, A., 2016. Seasonality of isoprenoid emissions from a primary rainforest in central Amazonia. Atmos. Chem. Phys. 16, 3903-3925. https://doi.org/10.5194/acp-163903-2016.

Apel, E.C., Riemer, D.D., Hills, A., Baugh, W., Orlando, J., Faloona, I., Tan, D., Brune, W., Lamb, B., Westberg, H., Carroll, M.A., Thornberry, T., Geron, C.D., 2002. Measurement and interpretation of isoprene fluxes and isoprene, methacrolein, and methyl vinyl ketone mixing ratios at the PROPHET site during the 1998 Intensive. J. Geophys. Res.: Atmospheres 107. https://doi.org/10.1029/2000jd000225. ACH 7-1-ACH 7-15.

Arnts, R.R., 2010. Evaluation of adsorbent sampling tube materials and Tenax-TA for analysis of volatile biogenic organic compounds. Atmos. Environ. 44, 1579-1584. https://doi.org/10.1016/j.atmosenv.2010.01.004.

Arnts, R.R., Mowry, F.L., Hampton, G.A., 2013. A high-frequency response relaxed eddy accumulation flux measurement system for sampling short-lived biogenic volatile organic compounds. J. Geophys. Res.: Atmospheres 118, 4860-4873. https://doi. org/10.1002/jgrd.50215.

Bai, J., Guenther, A., Turnipseed, A., Duhl, T., 2015. Seasonal and interannual variations in whole-ecosystem isoprene and monoterpene emissions from a temperate mixed forest in Northern China. Atmos. Pollut. Res. 6, 696-707. https://doi.org/10.5094/ APR. 2015.078.

Bai, J., Guenther, A., Turnipseed, A., Duhl, T., Yu, S., Wang, B., 2016. Seasonal variations in whole-ecosystem BVOC emissions from a subtropical bamboo plantation in China. Atmos. Environ. 124, 12-21. https://doi.org/10.1016/j.atmosenv.2015.11.008.

Bai, J., Guenther, A., Turnipseed, A., Duhl, T., Greenberg, J., 2017. Seasonal and interannual variations in whole-ecosystem BVOC emissions from a subtropical plantation in China. Atmos. Environ. 161, 176-190. https://doi.org/10.1016/j atmosenv.2017.05.002.

Baker, B., Guenther, A., Greenberg, J., Fall, R., 2001. Canopy level fluxes of 2-Methyl-3buten-2-ol, acetone, and methanol by a portable relaxed eddy accumulation system. Environ. Sci. Technol. 35, 1701-1708. https://doi.org/10.1021/es001007j.

Baker, B., Bai, J.-H., Johnson, C., Cai, Z.-T., Li, Q.-J., Wang, Y.-F., Guenther, A. Greenberg, J., Klinger, L., Geron, C., Rasmussen, R., 2005. Wet and dry season ecosystem level fluxes of isoprene and monoterpenes from a southeast Asian secondary forest and rubber tree plantation. Atmos. Environ. 39, 381-390. https:// doi.org/10.1016/j.atmosenv.2004.07.033.

Baker, J.M., Norman, J.M., Bland, W.L., 1992. Field-scale application of flux measurement by conditional sampling. Agric. For. Meteorol. 62, 31-52. https://doi org/10.1016/0168-1923(92)90004-N.

Baldocchi, D.D., Hincks, B.B., Meyers, T.P., 1988. Measuring biosphere-atmosphere exchanges of biologically related gases with micrometeorological methods. Ecology 69, 1331-1340. https://doi.org/10.2307/1941631.

Barkley, M.P., Palmer, P.I., De Smedt, I., Karl, T., Guenther, A., Van Roozendael, M., 2009. Regulated large-scale annual shutdown of Amazonian isoprene emissions? Geophys. Res. Lett. 36, 10, 1029/2008gl036843.
Baum, K.A., Ham, J.M., 2009. Adaptation of a speciation sampling cartridge for measuring ammonia flux from cattle feedlots using relaxed eddy accumulation. Atmos. Environ. 43, 1753-1759. https://doi.org/10.1016/j.atmosenv.2008.12.021. Bonal, D., Bosc, A., Ponton, S., Goret, J.-Y., Burban, B., Gross, P., Bonnefond, J.-M., Elbers, J., Longdoz, B., Epron, D., Guehl, J.-M., Granier, A., 2008. Impact of severe dry season on net ecosystem exchange in the Neotropical rainforest of French Guiana. Global Change Biol. 14, 1917-1933. https://doi.org/10.1111/j.13652486.2008.01610.x.

Bowling, D.R., Turnipseed, A.A., Delany, A.C., Baldocchi, D.D., Greenberg, J.P., Monson, R.K., 1998. The use of relaxed eddy accumulation to measure biosphereatmosphere exchange of isoprene and other biological trace gases. Oecologia 116 306-315.

Businger, J.A., Oncley, S.P., 1990. Flux measurement with conditional sampling. J. Atmos. Ocean. Technol. 7, 349-352. https://doi.org/10.1175/1520-0426(1990) $007<0349$ :fmwcs $>2.0$. co; 2 .

Carroll, M.A., Bertman, S.B., Shepson, P.B., 2001. Overview of the program for research on oxidants: PHotochemistry, emissions, and transport (PROPHET) summer 1998 measurements intensive. J. Geophys. Res.: Atmospheres 106, 24275-24288. https:// doi.org/10.1029/2001jd900189.

Ciccioli, P., Brancaleoni, E., Frattoni, M., Marta, S., Brachetti, A., Vitullo, M., Tirone, G., Valentini, R., 2003. Relaxed eddy accumulation, a new technique for measuring emission and deposition fluxes of volatile organic compounds by capillary gas chromatography and mass spectrometry. J. Chromatogr. A 985, 283-296. https:// doi.org/10.1016/S0021-9673(02)01731-4.

Dettmer, K., Knobloch, T., Engewald, W., 2000. Stability of reactive low boiling hydrocarbons on carbon based adsorbents typically used for adsorptive enrichment and thermal desorption. Fresen. J. Anal. Chem. 366, 70-78. https://doi.org/ $10.1007 /$ s002160050014.

Gallagher, M.W., Clayborough, R., Beswick, K.M., Hewitt, C.N., Owen, S., Moncrieff, J., Pilegaard, K., 2000. Assessment of a relaxed eddy accumulation for measurements of fluxes of biogenic volatile organic compounds: study over arable crops and a mature beech forest. Atmos. Environ. 34, 2887-2899. https://doi.org/10.1016/S1352-2310 (00)00066-2.

Gaman, A., Rannik, Ü., Aalto, P., Pohja, T., Siivola, E., Kulmala, M., Vesala, T., 2004. Relaxed eddy accumulation system for size-resolved aerosol particle flux measurements. J. Atmos. Ocean. Technol. 21, 933-943. https://doi.org/10.1175/ 1520-0426(2004)021<0933:reasfs > 2.0.co;2.

Graus, M., Hansel, A., Wisthaler, A., Lindinger, C., Forkel, R., Hauff, K., Klauer, M., Pfichner, A., Rappenglück, B., Steigner, D., Steinbrecher, R., 2006. A relaxed-eddyaccumulation method for the measurement of isoprenoid canopy-fluxes using an online gas-chromatographic technique and PTR-MS simultaneously. Atmos. Environ. 40, 43-54. https://doi.org/10.1016/j.atmosenv.2005.09.094.

Greenberg, J.P., Lee, B., Helmig, D., Zimmerman, P.R., 1994. Fully automated gas chromatograph-flame ionization detector system for the in situ determination of atmospheric nonmethane hydrocarbons at low parts per trillion concentration. J. Chromatogr. A 676, 389-398. https://doi.org/10.1016/0021-9673(94)80439-7.

Greenberg, J.P., Guenther, A., Harley, P., Otter, L., Veenendaal, E.M., Hewitt, C.N., James, A.E., Owen, S.M., 2003. Eddy flux and leaf-level measurements of biogenic VOC emissions from mopane woodland of Botswana. J. Geophys. Res.: Atmospheres 108. https://doi.org/10.1029/2002jd002317.

Gu, L., Pallardy, S.G., Yang, B., Hosman, K.P., Mao, J., Ricciuto, D., Shi, X., Sun, Y., 2016. Testing a land model in ecosystem functional space via a comparison of observed and modeled ecosystem flux responses to precipitation regimes and associated stresses in a Central U.S. forest. J. Geophys. Res.: Biogeosciences 121, 1884-1902. https://doi. org/10.1002/2015jg003302.

Guenther, A., Hewitt, C.N., Erickson, D., Fall, R., Geron, C., Graedel, T., Harley, P., Klinger, L., Lerdau, M., Mckay, W.A., Pierce, T., Scholes, B., Steinbrecher, R., Tallamraju, R., Taylor, J., Zimmerman, P., 1995. A global model of natural volatile organic compound emissions. J. Geophys. Res.: Atmospheres 100, 8873-8892. https://doi.org/10.1029/94jd02950.

Guenther, A., Karl, T., Harley, P., Wiedinmyer, C., Palmer, P.I., Geron, C., 2006. Estimates of global terrestrial isoprene emissions using MEGAN (model of emissions of gases and aerosols from nature). Atmos. Chem. Phys. 6, 3181-3210. https://doi. org/10.5194/acp-6-3181-2006.

Guenther, A.B., Hills, A.J., 1998. Eddy covariance measurement of isoprene fluxes. J. Geophys. Res.: Atmospheres 103, 13145-13152. https://doi.org/10.1029/ 97jd03283.

Guenther, A.B., Jiang, X., Heald, C.L., Sakulyanontvittaya, T., Duhl, T., Emmons, L.K., Wang, X., 2012. The Model of Emissions of Gases and Aerosols from Nature version 2.1 (MEGAN2.1): an extended and updated framework for modeling biogenic emissions. Geosci. Model Dev. (GMD) 5, 1471-1492. https://doi.org/10.5194/gmd5-1471-2012.

Hallquist, M., Wenger, J.C., Baltensperger, U., Rudich, Y., Simpson, D., Claeys, M., Dommen, J., Donahue, N.M., George, C., Goldstein, A.H., Hamilton, J.F., Herrmann, H., Hoffmann, T., Iinuma, Y., Jang, M., Jenkin, M.E., Jimenez, J.L., Kiendler-Scharr, A., Maenhaut, W., McFiggans, G., Mentel, T.F., Monod, A., Prévôt, A.S.H., Seinfeld, J.H., Surratt, J.D., Szmigielski, R., Wildt, J., 2009. The formation, properties and impact of secondary organic aerosol: current and emerging issues. Atmos. Chem. Phys. 9, 5155-5236. https://doi.org/10.5194/acp-95155-2009.

Helmig, D., Vierling, L., 1995. Water adsorption capacity of the solid adsorbents Tenax TA, Tenax GR, carbotrap, carbotrap C, carbosieve SIII, and carboxen 569 and water management techniques for the atmospheric sampling of volatile organic trace gases. Anal. Chem. 67, 4380-4386. https://doi.org/10.1021/ac00119a029. 
Helmig, D., 1997. Ozone removal techniques in the sampling of atmospheric volatile organic trace gases. Atmos. Environ. 31, 3635-3651. https://doi.org/10.1016 S1352-2310(97)00144-1.

Hicks, B.B., Wesely, M.L., 1978. An Examination of Some Micrometeorological Methods for Measuring Dry Deposition. U. S. EPA Report, Research Triangle Park, North Carolina. EPA-600/7-78-116.

Hoffmann, T., Odum, J.R., Bowman, F., Collins, D., Klockow, D., Flagan, R.C., Seinfeld, J. H., 1997. formation of organic aerosols from the oxidation of biogenic hydrocarbons. J. Atmos. Chem. 26, 189-222. https://doi.org/10.1023/a:1005734301837.

Karl, T., Potosnak, M., Guenther, A., Clark, D., Walker, J., Herrick, J.D., Geron, C., 2004. Exchange processes of volatile organic compounds above a tropical rain forest: implications for modeling tropospheric chemistry above dense vegetation. J. Geophys. Res.: Atmospheres 109. https://doi.org/10.1029/2004jd004738.

Karl, T.G., Spirig, C., Rinne, J., Stroud, C., Prevost, P., Greenberg, J., Fall, R., Guenther, A., 2002. Virtual disjunct eddy covariance measurements of organic compound fluxes from a subalpine forest using proton transfer reaction mass spectrometry. Atmos. Chem. Phys. 2, 279-291. https://doi.org/10.5194/acp-2-2792002.

Kaser, L., Karl, T., Guenther, A., Graus, M., Schnitzhofer, R., Turnipseed, A., Fischer, L., Harley, P., Madronich, M., Gochis, D., Keutsch, F.N., Hansel, A., 2013a. Undisturbed and disturbed above canopy ponderosa pine emissions: PTR-TOF-MS measurements and MEGAN 2.1 model results. Atmos. Chem. Phys. 13, 11935-11947. https://doi. org/10.5194/acp-13-11935-2013.

Kaser, L., Karl, T., Schnitzhofer, R., Graus, M., Herdlinger-Blatt, I.S., DiGangi, J.P., Sive, B., Turnipseed, A., Hornbrook, R.S., Zheng, W., Flocke, F.M., Guenther, A., Keutsch, F.N., Apel, E., Hansel, A., 2013b. Comparison of different real time VOC measurement techniques in a ponderosa pine forest. Atmos. Chem. Phys. 13 2893-2906. https://doi.org/10.5194/acp-13-2893-2013.

Kim, S., Wolfe, G.M., Mauldin, L., Cantrell, C., Guenther, A., Karl, T., Turnipseed, A. Greenberg, J., Hall, S.R., Ullmann, K., Apel, E., Hornbrook, R., Kajii, Y. Nakashima, Y., Keutsch, F.N., DiGangi, J.P., Henry, S.B., Kaser, L., Schnitzhofer, R., Graus, M., Hansel, A., Zheng, W., Flocke, F.F., 2013. Evaluation of HOx sources and cycling using measurement-constrained model calculations in a 2-methyl-3-butene2-ol (MBO) and monoterpene (MT) dominated ecosystem. Atmos. Chem. Phys. 13, 2031-2044. https://doi.org/10.5194/acp-13-2031-2013.

Krofcheck, D.J., Eitel, J.U.H., Vierling, L.A., Schulthess, U., Hilton, T.M., DettweilerRobinson, E., Pendleton, R., Litvak, M.E., 2014. Detecting mortality induced structural and functional changes in a piñon-juniper woodland using Landsat and RapidEye time series. Rem. Sens. Environ. 151, 102-113. https://doi.org/10.1016/j. rse.2013.11.009.

Lenschow, D.H., 1995. Micrometeorological techniques for measuring biosphereatmosphere trace gas exchange. In: Mattoon, P.A., Harris, R.C. (Eds.), Biogenic Trace Gases: Measuring Emissions from Soil and Water. Blackwell Science, Oxford, pp. 126-163.

Monson, R.K., Prater, M.R., Hu, J., Burns, S.P., Sparks, J.P., Sparks, K.L., Scott-Denton, L. E., 2010. Tree species effects on ecosystem water-use efficiency in a high-elevation, subalpine forest. Oecologia 162, 491-504. https://doi.org/10.1007/s00442-0091465-z.

Moore, C.J., 1986. Frequency response corrections for eddy correlation systems. Boundary-Layer Meteorol. 37, 17-35. https://doi.org/10.1007/BF00122754.

Nie, D., Kleindienst, T.E., Arnts, R.R., Sickles II, J.E., 1995. The design and testing of a relaxed eddy accumulation system. J. Geophys. Res.: Atmospheres 100, 11415-11423. https://doi.org/10.1029/95jd01042.

Olofsson, M., Ek-Olausson, B., Ljungström, E., Langer, S., 2003. Flux of organic compounds from grass measured by relaxed eddy accumulation technique. J. Environ. Monit. 5, 963-970. https://doi.org/10.1039/B303329E.

Oncley, S.P., Delany, A.C., Horst, T.W., Tans, P.P., 1993. Verification of flux measurement using relaxed eddy accumulation. Atmos. Environ. Part A Gen. Top. 27, 2417-2426. https://doi.org/10.1016/0960-1686(93)90409-R.

Ortega, J., Turnipseed, A., Guenther, A.B., Karl, T.G., Day, D.A., Gochis, D., Huffman, J. A., Prenni, A.J., Levin, E.J.T., Kreidenweis, S.M., DeMott, P.J., Tobo, Y., Patton, E.G.,
Hodzic, A., Cui, Y.Y., Harley, P.C., Hornbrook, R.S., Apel, E.C., Monson, R.K., Eller, A.S.D., Greenberg, J.P., Barth, M.C., Campuzano-Jost, P., Palm, B.B., Jimenez, J.L., Aiken, A.C., Dubey, M.K., Geron, C., Offenberg, J., Ryan, M.G., Fornwalt, P.J., Pryor, S.C., Keutsch, F.N., DiGangi, J.P., Chan, A.W.H., Goldstein, A. H., Wolfe, G.M., Kim, S., Kaser, L., Schnitzhofer, R., Hansel, A., Cantrell, C.A., Mauldin, R.L., Smith, J.N., 2014. Overview of the Manitou Experimental Forest Observatory: site description and selected science results from 2008 to 2013. Atmos. Chem. Phys. 14, 6345-6367. https://doi.org/10.5194/acp-14-6345-2014.

Pattey, E., Desjardins, R.L., Rochette, P., 1993. Accuracy of the relaxed eddyaccumulation technique, evaluated using $\mathrm{CO} 2$ flux measurements. Boundary-Layer Meteorol. 66, 341-355. https://doi.org/10.1007/bf00712728.

Potosnak, M.J., LeStourgeon, L., Pallardy, S.G., Hosman, K.P., Gu, L., Karl, T., Geron, C., Guenther, A.B., 2014. Observed and modeled ecosystem isoprene fluxes from an oakdominated temperate forest and the influence of drought stress. Atmos. Environ. 84, 314-322. https://doi.org/10.1016/j.atmosenv.2013.11.055.

Rhew, R.C., Deventer, M.J., Turnipseed, A.A., Warneke, C., Ortega, J., Shen, S., Martinez, L., Koss, A., Lerner, B.M., Gilman, J.B., Smith, J.N., Guenther, A.B., de Gouw, J.A., 2017. Ethene, propene, butene and isoprene emissions from a ponderosa pine forest measured by relaxed eddy accumulation. Atmos. Chem. Phys. 17, 13417-13438. https://doi.org/10.5194/acp-17-13417-2017.

Rinne, H.J.I., Guenther, A.B., Greenberg, J.P., Harley, P.C., 2002. Isoprene and monoterpene fluxes measured above Amazonian rainforest and their dependence on light and temperature. Atmos. Environ. 36, 2421-2426. https://doi.org/10.1016/ S1352-2310(01)00523-4.

Rinne, J., Karl, T., Guenther, A., 2016. Simple, stable, and affordable: towards long-term ecosystem scale flux measurements of VOCs. Atmos. Environ. 131 https://doi.org/ 10.1016/j.atmosenv.2016.02.005.

Sarkar, C., Sinha, V., Kumar, V., Rupakheti, M., Panday, A., Mahata, K.S., Rupakheti, D., Kathayat, B., Lawrence, M.G., 2016. Overview of VOC emissions and chemistry from PTR-TOF-MS measurements during the SusKat-ABC campaign: high acetaldehyde, isoprene and isocyanic acid in wintertime air of the Kathmandu Valley. Atmos. Chem. Phys. 16, 3979-4003. https://doi.org/10.5194/acp-16-3979-2016.

Sarkar, C., Guenther, A.B., Park, J.H., Seco, R., Alves, E., Batalha, S., Santana, R., Kim, S., Smith, J., Tóta, J., Vega, O., 2020. PTR-TOF-MS eddy covariance measurements of isoprene and monoterpene fluxes from an eastern Amazonian rainforest. Atmos. Chem. Phys. 20, 7179-7191. https://doi.org/10.5194/acp-20-7179-2020.

Schade, G.W., Goldstein, A.H., 2001. Fluxes of oxygenated volatile organic compounds from a ponderosa pine plantation. J. Geophys. Res.: Atmospheres 106, 3111-3123. https://doi.org/10.1029/2000jd900592.

Schery, S.D., Wasiolek, P.T., Nemetz, B.M., Yarger, F.D., Whittlestone, S., 1998. Relaxed eddy accumulator for flux measurement of nanometer-size particles. Aerosol. Sci. Technol. 28, 159-172. https://doi.org/10.1080/02786829808965518.

Seco, R., Karl, T., Guenther, A., Hosman, K.P., Pallardy, S.G., Gu, L., Geron, C., Harley, P., Kim, S., 2015. Ecosystem-scale volatile organic compound fluxes during an extreme drought in a broadleaf temperate forest of the Missouri Ozarks (central USA). Global Change Biol. 21, 3657-3674. https://doi.org/10.1111/gcb.12980.

Turnipseed, A.A., Pressley, S.N., Karl, T., Lamb, B., Nemitz, E., Allwine, E., Cooper, W.A., Shertz, S., Guenther, A.B., 2009. The use of disjunct eddy sampling methods for the determination of ecosystem level fluxes of trace gases. Atmos. Chem. Phys. 9, 981-994. https://doi.org/10.5194/acp-9-981-2009.

Westberg, H., Lamb, B., Hafer, R., Hills, A., Shepson, P., Vogel, C., 2001. Measurement of isoprene fluxes at the PROPHET site. J. Geophys. Res.: Atmospheres 106, 24347-24358. https://doi.org/10.1029/2000jd900735.

Wilczak, J.M., Oncley, S.P., Stage, S.A., 2001. Sonic anemometer tilt correction algorithms. Boundary-Layer Meteorol. 99, 127-150. https://doi.org/10.1023/A 1018966204465.

Zhu, T., Wang, D., Desjardins, R.L., Macpherson, J.I., 1999. Aircraft-based volatile organic compounds flux measurements with relaxed eddy accumulation. Atmos. Environ. 33, 1969-1979. https://doi.org/10.1016/S1352-2310(98)00098-3. 